\title{
Secondary formation of nitrated phenols: insights from observations during the Uintah Basin Winter Ozone Study (UBWOS) 2014
}

\author{
Bin Yuan ${ }^{1,2}$, John Liggio ${ }^{3}$, Jeremy Wentzell ${ }^{3}$, Shao-Meng Li ${ }^{3}$, Harald Stark ${ }^{2,4}$, James M. Roberts ${ }^{1}$, Jessica Gilman ${ }^{1,2}$ \\ Brian Lerner $^{1,2}$, Carsten Warneke ${ }^{1,2}$, Rui Li ${ }^{1,2}$, Amy Leithead ${ }^{3}$, Hans D. Osthoff ${ }^{5}$, Robert Wild ${ }^{1,2}$, Steven S. Brown ${ }^{1,6}$, \\ and Joost A. de Gouw ${ }^{1,2,6}$ \\ ${ }^{1}$ NOAA Earth System Research Laboratory (ESRL), Chemical Sciences Division, Boulder, CO, USA \\ ${ }^{2}$ Cooperative Institute for Research in Environmental Sciences, University of Colorado at Boulder, Boulder, CO, USA \\ ${ }^{3}$ Environment Canada, Science and Technology Branch, Toronto, ON, Canada \\ ${ }^{4}$ Aerodyne Research Inc., Billerica, MA, USA \\ ${ }^{5}$ Department of Chemistry, University of Calgary, Calgary, AB, Canada \\ ${ }^{6}$ Department of Chemistry and Biochemistry, University of Colorado at Boulder, CO, USA
}

Correspondence to: Bin Yuan (bin.yuan@noaa.gov)

Received: 30 September 2015 - Published in Atmos. Chem. Phys. Discuss.: 23 October 2015

Revised: 29 January 2016 - Accepted: 12 February 2016 - Published: 24 February 2016

\begin{abstract}
We describe the results from online measurements of nitrated phenols using a time-of-flight chemical ionization mass spectrometer (ToF-CIMS) with acetate as reagent ion in an oil and gas production region in January and February of 2014. Strong diurnal profiles were observed for nitrated phenols, with concentration maxima at night. Based on known markers $\left(\mathrm{CH}_{4}, \mathrm{NO}_{x}, \mathrm{CO}_{2}\right)$, primary emissions of nitrated phenols were not important in this study. A box model was used to simulate secondary formation of phenol, nitrophenol (NP), and dinitrophenols (DNP). The box model results indicate that oxidation of aromatics in the gas phase can explain the observed concentrations of NP and DNP in this study. Photolysis was the most efficient loss pathway for NP in the gas phase. We show that aqueous-phase reactions and heterogeneous reactions were minor sources of nitrated phenols in our study. This study demonstrates that the emergence of new ToF-CIMS (including PTR-TOF) techniques allows for the measurement of intermediate oxygenates at low levels and these measurements improve our understanding on the evolution of primary VOCs in the atmosphere.
\end{abstract}

\section{Introduction}

Nitrated phenols are a family of aromatic compounds with both nitro $\left(-\mathrm{NO}_{2}\right)$ and hydroxyl groups (-OH) connected to a benzene ring. Nitrated phenols have been detected in the gas phase, aerosol, cloud water, and rainwater (Harrison et al., 2005a). Many studies have shown that nitrated phenols are one of the important components of brown carbon in aerosol (Desyaterik et al., 2013; Mohr et al., 2013; Zhang et al., 2013; Lin et al., 2015), as they absorb light in the atmosphere (Bejan et al., 2007). Photolysis of some nitrated phenols was reported to produce nitrous acid (HONO) (Bejan et al., 2006) and hydroxyl (OH) radicals (Cheng et al., 2009), while the oxidation and photolysis of them contribute to secondary organic aerosol (SOA) formation, especially in biomass burning plumes (Mohr et al., 2013; Kitanovski et al., 2012; Lauraguais et al., 2014). There is also evidence that nitrated phenols are phytotoxic and contribute to forest decline (Rippen et al., 1987; Natangelo et al., 1999). Some nitrated phenols are known to be mutagenic and are of concern to human health (Fernandez et al., 1992).

Sources of nitrated phenols in the atmosphere include emissions from vehicle exhaust (Inomata et al., 2013; Tremp et al., 1993; Sekimoto et al., 2013) and biomass burning (Mohr et al., 2013). Nitrated phenols are also produced from photooxidation of aromatic hydrocarbons in the atmosphere: 


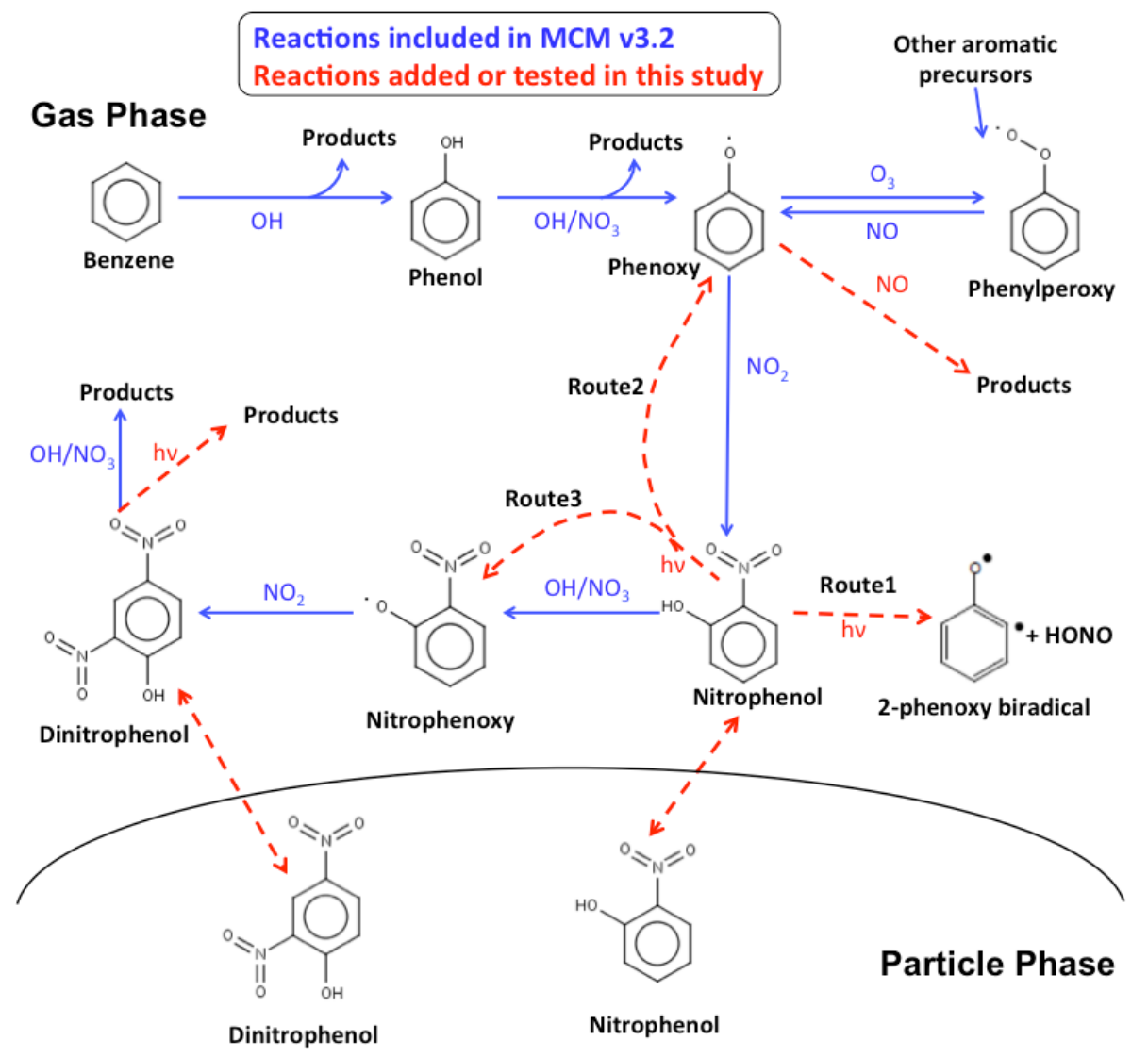

Figure 1. Formation of phenol, nitrophenol (NP), and dinitrophenol (DNP) from the photooxidation of benzene in the atmosphere (Jenkin et al., 2003). Reactions in blue are included in the MCM v3.2, whereas reactions in red are added or evaluated in this study. For NP, DNP, and the intermediate radicals, other isomers are expected but not shown for the sake of clarity.

for example, benzene oxidizes to 2-nitrophenol (2-NP) and 4-nitrophenol (4-NP), and toluene oxidizes to methylnitrophenols (MNP) (Harrison et al., 2005a). Figure 1 shows the reactions leading to secondary formation of NP and dinitrophenols (DNP) in the atmosphere (Jenkin et al., 2003). Oxidation of benzene by $\mathrm{OH}$ radicals forms phenol, and further reactions of phenol with either $\mathrm{OH}$ or $\mathrm{NO}_{3}$ radicals yield phenoxy $\left(\mathrm{C}_{6} \mathrm{H}_{5} \mathrm{O}\right)$ radicals, which react further with $\mathrm{NO}_{2}$ to generate NP. In addition to benzene oxidation, $\mathrm{C}_{6} \mathrm{H}_{5} \mathrm{O}$ radicals are also generated from the reaction of $\mathrm{NO}$ with phenyl peroxy $\left(\mathrm{C}_{6} \mathrm{H}_{5} \mathrm{O}_{2}\right)$ radicals, a product from reactions of some other aromatic precursors, e.g., benzaldehyde (Caralp et al., 1999). Further oxidation of nitrated phenols by obtaining another nitro group produces DNP. The yields of NP from phenol oxidation by $\mathrm{OH}$ radicals (Atkinson et al., 1992; Olariu et al., 2002; Berndt and Boge, 2003) and $\mathrm{NO}_{3}$ radicals (Atkinson et al., 1992; Bolzacchini et al., 2001) have been reported. Berndt and Boge (2003) also showed that the NP yield from $\mathrm{OH}$ oxidation of phenol increases at higher $\mathrm{NO}_{2}$ concentrations. In addition to gas-phase reactions, nitrated phenols are formed from aqueous-phase reactions in aerosol or cloud water (Vione et al., 2001, 2005). The importance of the aqueous reactions compared to gas-phase reactions is highly dependent on liquid water content in the atmosphere (Harrison et al., 2005b).

The sinks of nitrated phenols in the gas phase include reactions with $\mathrm{OH}$ radicals (Atkinson et al., 1992; Bejan et al., 2007), with $\mathrm{NO}_{3}$ radicals (Atkinson et al., 1992), with chlorine atoms (Bejan et al., 2015) and photolysis (Bejan et al., 2007; Chen et al., 2011). It has been proposed that photolysis is the dominant gas-phase atmospheric loss for nitrated phenols (Bejan et al., 2007). Despite the importance of photolysis of nitrated phenols, the photolysis frequency of nitrated phenols under ambient conditions has only been reported in a single non-peer-reviewed publication (1.4\% of photolysis frequency of $\mathrm{NO}_{2}$ ) (Bardini, 2006). The chemical products from photolysis of nitrated phenols have been proposed, but the proposed products have not been fully evaluated against experimental results (Bejan et al., 2006). Nitrated phenols are also removed by various processes in the aqueous phase, including reactions with $\mathrm{OH}, \mathrm{NO}_{3}$, and photolysis (Vione et al., 2009).

Measurements of nitrated phenols have been mainly conducted using offline methods (Harrison et al., 2005a). Air 
samples are usually collected on filters or cartridges and then analyzed by liquid chromatography (LC) methods (Rubio et al., 2012; Harrison et al., 2005a; Delhomme et al., 2010). These detection methods are time-consuming and measurements as a function of the time of day are not usually possible (Delhomme et al., 2010). The lack of fast-response online measurements has prevented, at least partially, a thorough investigation of sources and sinks of nitrated phenols. Recently, Mohr et al. (2013) deployed a chemical ionization mass spectrometer (CIMS) using acetate as the reagent ion to measure nitrated phenols online in the particle phase in the winter in London, and based on their measurements the authors concluded that nitrated phenols were mainly from wood burning in this region of the atmosphere.

In this study, we conducted high-time-resolution measurements of nitrated phenols in the gas phase at a site in an oil and gas production region in winter. High concentrations of ozone and secondary products (Edwards et al., 2014) were observed at this site, as the result of photochemical degradation of large amounts of alkanes and aromatics emitted from oil and gas production in this region (Warneke et al., 2014). Using the present data set, we investigate diurnal variations, sources and sinks of nitrated phenols. We use a box model to analyze the budget of nitrated phenols in the atmosphere, and provide insights into the formation mechanism of nitrated phenols.

\section{Measurements}

The Uintah Basin Winter Ozone Study (UBWOS 2014) was conducted in January and February of 2014 at the Horse Pool site in the Uintah Basin, where over 10000 active oil and gas wells are located.

\subsection{Acetate ToF-CIMS}

\subsubsection{Instrument operation}

An Aerodyne time-of-flight (ToF) CIMS (Lee et al., 2014) that uses acetate $\left(\mathrm{CH}_{3} \mathrm{C}(\mathrm{O}) \mathrm{O}^{-}\right)$as the reagent ion was deployed at the Horse Pool site during UBWOS 2014 to measure organic acids, inorganic acids and nitrated phenols. These compounds are ionized in the ionmolecule reaction region (IMR, $61.8 \pm 0.3 \mathrm{mbar}$ ) via proton abstraction (Veres et al., 2008) or by a sequence of clustering-declustering/deprotonation reactions (Brophy and Farmer, 2015) in the reaction with acetate ions. Acetate ions were produced by introducing saturated acetic anhydride $/ \mathrm{N}_{2}$ mixture $\left(5 \mathrm{~mL} \mathrm{~min}^{-1}\right)$ mixed with another flow of $\mathrm{N}_{2}\left(2.5 \mathrm{~L} \mathrm{~min}^{-1}\right)$ into a polonium-210 $\left({ }^{210} \mathrm{Po}\right)$ radioactive source. The instrument was operated under strong declustering conditions by applying voltages in the first quadrupole ion guide (i.e., SSQ, $2.50 \pm 0.01 \mathrm{mbar}$ ) during UBWOS 2014, with the ratio of acetate cluster $\left(\mathrm{CH}_{3} \mathrm{C}(\mathrm{O}) \mathrm{O}^{-} \cdot \mathrm{CH}_{3} \mathrm{C}(\mathrm{O}) \mathrm{OH}\right) /$ acetate $\left(\mathrm{CH}_{3} \mathrm{C}(\mathrm{O}) \mathrm{O}^{-}\right)$at
$0.4 \pm 0.1 \%$. Under such declustering conditions, the conjugate anions were usually observed as the product ions, with little contribution from cluster ions. The reagent ions and product ions are analyzed using a high-resolution time-offlight mass spectrometer (Tofwerk AG, Switzerland). The signals of acetate ion were approximately $1-2 \times 10^{6}$ counts per second (cps) during the campaign (ToF extraction frequency $=25 \mathrm{kHz}$ ). The mass resolution of the ToF analyzer during UBWOS 2014 was approximately 3200 for ions of $m / z>200$.

Background signals associated with the instrument were measured every $2 \mathrm{~h}$ for $15 \mathrm{~min}$ by passing ambient air through three stages of zero air generation: a platinum catalytic converter heated to $350^{\circ} \mathrm{C}$, nylon wool coated with sodium bicarbonate $\left(\mathrm{NaHCO}_{3}\right)$, and activated charcoal, which were used in series to remove acidic gases from the sample air and determine instrument backgrounds. During the UBWOS 2014 study, two CIMS inlets constructed from Teflon tubing heated to $\sim 40^{\circ} \mathrm{C}$ with similar lengths $(\sim 10 \mathrm{~m})$ placed at heights of 1 and $18.5 \mathrm{~m}$ above ground were switched automatically every $30 \mathrm{~min}$ during the period of 24 January1 February in order to measure the vertical concentration gradient of nitrated phenols and other acidic gases. Inlet switching between a long heated and a short unheated inlet was conducted during 1-5 February in order to explore possible inlet interferences to CIMS measurements of nitrated phenols from the long heated inlet. We did not observe differences in signals between the long and short inlets for nitrated phenols except DNP (Fig. S1 in the Supplement), indicating that potential loss in the sampling line was minimal for the reported single nitrated phenols in this study. The inlet issues for DNP will be discussed in Sect. 2.1.2.

\subsubsection{Data processing}

The ToF-CIMS data were processed using the Tofware software package (www.tofwerk.com/tofware) written in Igor Pro (Wavemetrics Inc., USA). The detailed data processing procedures are presented in recent studies (Yatavelli et al., 2014; Stark et al., 2015). Post-measurement mass calibrations were performed using nine isolated ions: $m / z 31.9904\left(\mathrm{O}_{2}^{-}\right), m / z 34.9694\left(\mathrm{Cl}^{-}\right), m / z 44.9982$ $\left(\mathrm{CHO}_{2}^{-}\right), m / z 59.0139\left(\mathrm{C}_{2} \mathrm{H}_{3} \mathrm{O}_{2}^{-}\right), m / z 61.9884\left(\mathrm{NO}_{3}^{-}\right)$, $m / z \quad 143.9840 \quad\left(\mathrm{C}_{3} \mathrm{~F}_{4} \mathrm{O}_{2}^{-}\right), \quad m / z \quad 162.9824 \quad\left(\mathrm{C}_{3} \mathrm{~F}_{5} \mathrm{O}_{2}^{-}\right)$, $m / z 193.9808\left(\mathrm{C}_{4} \mathrm{~F}_{6} \mathrm{O}_{2}^{-}\right)$, and $m / z 243.9776\left(\mathrm{C}_{5} \mathrm{~F}_{8} \mathrm{O}_{2}^{-}\right)$. The four fluorine-containing ions in the list were released from the Teflon inlet during UBWOS 2014 and their persistent presence was used for mass calibration. The accuracy of mass calibration was $4.7 \pm 1.9 \mathrm{ppm}$ for the whole campaign and the errors of mass calibration for individual ions were usually within $10 \mathrm{ppm}$ (average $+3 \sigma$ ). The fitted raw signals for the targeted compounds were normalized using an acetate signal at the level of $1 \times 10^{6} \mathrm{cps}$, and the normalized signal has a unit of normalized counts per second (ncps). 
The fitted $\mathrm{m} / \mathrm{z}$ used for quantification of concentrations of nitrated phenols in the acetate CIMS are $\mathrm{m} / z$ 138.0197 $\left(\mathrm{C}_{6} \mathrm{H}_{4} \mathrm{NO}_{3}^{-}\right)$for $\mathrm{NP}, m / z \quad 152.0353\left(\mathrm{C}_{7} \mathrm{H}_{6} \mathrm{NO}_{3}^{-}\right)$for MNP, $m / z \quad 166.0510\left(\mathrm{C}_{8} \mathrm{H}_{8} \mathrm{NO}_{3}^{-}\right)$for dimethylnitrophenol+ethylnitrophenol (DMNP) and $\mathrm{m} / z \quad 183.0047$ $\left(\mathrm{C}_{6} \mathrm{H}_{3} \mathrm{~N}_{2} \mathrm{O}_{5}^{-}\right)$for DNP. Compounds with the same molecular formulas as nitrated phenols include phenyl nitrates/benzyl nitrates, methoxynitrobenzenes, nitrobenzyl alcohols, and hydroxycarboxylic acids derived from pyridine. The first three groups of compounds have lower acidities than acetic acid (Bartmess, 2015) and hence they are unlikely to be observed in acetate CIMS, while hydroxycarboxylic acids derived from pyridine are expected to be small in the atmosphere.

High-resolution (HR) peak fitting to $m / z 138, m / z 152$, and $m / z 183$ in the averaged mass spectra of ToF-CIMS on a typical day (25 January 2014) are shown as examples in Fig. 2. Isotope signals from lower masses (dark-green lines) accounted for small fractions of the $m / z$ signals. Multiple overlapping ion peaks were identified in the $m / z$ channels. In addition to nitrated phenols, several ions without deprotonation were also present in the even $m / z$ (e.g., $\mathrm{C}_{8} \mathrm{H}_{10} \mathrm{O}_{2}^{-}$at $m / z$ 138), possibly due to electron transfer reactions and/or fragmentation in the quadrupole ion guides (Stark et al., 2015). The signals of NP and MNP were either the largest or significantly larger than their neighboring peaks at their respective $m / z$, whereas the signal of DNP was much smaller than its neighboring peaks on 25 January 2014. Smaller ratios of the signals between the targeted peak and its neighboring peaks have been shown to deteriorate the precision of the fitted signals for the targeted peak (Cubison and Jimenez, 2015; Müller et al., 2011; Corbin et al., 2015). Based on the provided equations in Cubison and Jimenez (2015), the imprecision arising from mass calibration (not including counting error) for the signals of NP, MNP, and DNP are 3.2, 1.8, and $47 \%$ based on the mass spectra of 25 January, respectively. Imperfect mass calibration can also affect fitted magnitudes of ion signals. Figure $\mathrm{S} 2$ shows the sensitivity of the fitted signals of various masses as a function of the errors in mass calibration. The signal changes at $10 \mathrm{ppm}($ average $+3 \sigma)$ error of mass calibration relative to the perfect mass calibration (error $=0 \mathrm{ppm}$ ) for NP, MNP, and DNP signals are as high as 14,5 , and $81 \%$, respectively. The results from both precision calculation and sensitivity of fitted magnitudes indicate that the peak signals of NP and MNP can be fitted well with low uncertainties. The peak fitting at $m / z 166$ for DMNP shows similar results as $m / z 138$ for NP and $m / z 152$ for MNP. However, large uncertainties are associated with the peak signals of DNP on 25 January 2014, which is mainly affected by the $\mathrm{C}_{3} \mathrm{~F}_{6} \mathrm{HO}_{2}^{-}$ions $(\mathrm{m} / \mathrm{z}$ 182.9886) as indicated by the opposite behaviors of the DNP ion and $\mathrm{C}_{3} \mathrm{~F}_{6} \mathrm{HO}_{2}^{-}$ion in Fig. S2c.

The $\mathrm{C}_{3} \mathrm{~F}_{6} \mathrm{HO}_{2}^{-}$ion $(\mathrm{m} / z$ 182.9886) was released from the heated Teflon inlet along with other fluorine-containing
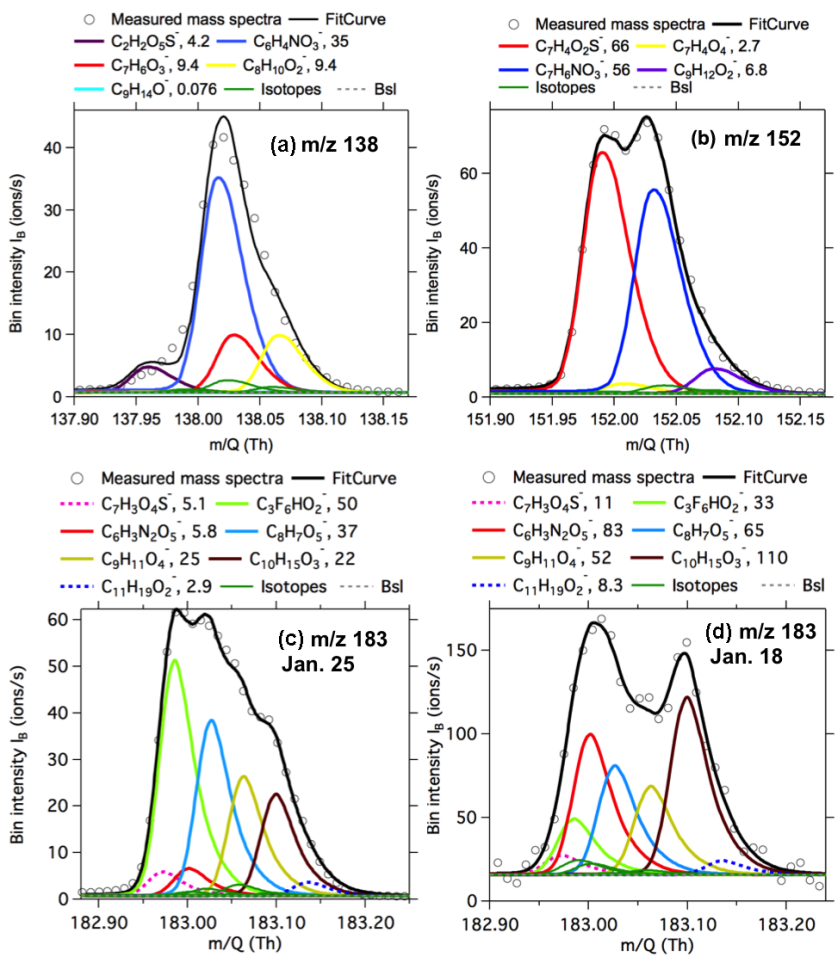

Figure 2. High-resolution peak fitting to the averaged mass spectra of acetate ToF-CIMS for $m / z 138$ (a), $m / z 152$ (b), and $m / z 183$ (c) on 25 January 2014 and $m / z 183$ (d) on 18 January 2014 during UBWOS 2014. The dark-green lines indicate the calculated isotope signals from lower masses.

ions that were used for mass calibration. The release of the $\mathrm{C}_{3} \mathrm{~F}_{6} \mathrm{HO}_{2}^{-}$ion was supported by much higher signals from the long heated inlet compared to the short unheated inlet when inlet-switching experiments were conducted in 25 February (Fig. S1). Long-heated inlets were used for most of the time during UBWOS 2014 (23 January-13 February), except during 18-22 January, when a short unheated inlet was used. The averaged mass spectra of $\mathrm{m} / z 183$ measured on 18 January is shown in Fig. 2d. Compared to the mass spectra on 25 January, $\mathrm{C}_{3} \mathrm{~F}_{6} \mathrm{HO}_{2}^{-}$signals on 18 January were lower and the signals of DNP were larger than those of $\mathrm{C}_{3} \mathrm{~F}_{6} \mathrm{HO}_{2}^{-}$ions. As a result, the uncertainty from peak fitting for the DNP ion was much lower on 18 January (Fig. S2d). Thus, we will only use measured DNP data in the beginning of the campaign (18-22 January), when the long heated inlet was not connected to the acetate CIMS and no inlet switching was performed.

The response of the CIMS instrument for nitrated phenols, including 2-NP, 4-NP, 2-methyl-4-nitrophenol, and 2,5dinitrophenol, was calibrated using a liquid calibration unit (LCU, IONICON Analytik). In the LCU, a water solution with known concentrations of the targeted compounds is nebulized and diluted by another gas stream at different flow rates to produce a gas standard at various concentrations 
Table 1. Sensitivities and detection limits of nitrated phenols in acetate ToF-CIMS.

\begin{tabular}{|c|c|c|c|c|c|c|c|}
\hline \multirow[t]{2}{*}{ Species } & \multirow[t]{2}{*}{ Abbreviation } & \multirow[t]{2}{*}{ Ion } & \multirow[t]{2}{*}{$m / z$} & \multicolumn{2}{|c|}{ Sensitivity } & \multicolumn{2}{|c|}{ Detection limit, $\mathrm{ppt}^{\mathrm{f}}$} \\
\hline & & & & Value, ncps ppt ${ }^{-1}$ & Ratio to $\mathrm{HCOOH}^{\mathrm{e}}$ & Method 1 & Method 2 \\
\hline Nitrophenol & $\mathrm{NP}$ & $\mathrm{C}_{6} \mathrm{H}_{4} \mathrm{NO}_{3}^{-}$ & 138.0197 & $13.2^{\mathrm{a}}$ & 2.6 & 0.18 & 0.45 \\
\hline Methylnitrophenol & MNP & $\mathrm{C}_{7} \mathrm{H}_{6} \mathrm{NO}_{3}^{-}$ & 152.0353 & $16.6^{\mathrm{b}}$ & 3.3 & 0.24 & 0.36 \\
\hline $\begin{array}{l}\text { Dimethylnitrophenol } \\
+ \text { ethylnitrophenol }\end{array}$ & DMNP & $\mathrm{C}_{8} \mathrm{H}_{8} \mathrm{NO}_{3}^{-}$ & 166.0510 & $16.6^{\mathrm{c}}$ & 3.3 & 0.14 & 0.36 \\
\hline Dinitrophenol & DNP & $\mathrm{C}_{6} \mathrm{H}_{3} \mathrm{~N}_{2} \mathrm{O}_{5}^{-}$ & 183.0047 & $10.3^{\mathrm{d}}$ & 2.0 & 0.23 & 0.58 \\
\hline
\end{tabular}

(Kaser et al., 2013). The results of the calibrations to various nitrated phenols are shown in Table 1 . The sensitivity of 4-NP in our instrument was determined to be higher than that of 2-NP by a factor of 2.1. A higher sensitivity of 4-NP in acetate CIMS was reported in Mohr et al. (2013), but in that study the difference was larger by 3 orders of magnitude (Mohr et al., 2013). The different sensitivity ratios of 4NP/2-NP can be caused by many different instrumental conditions between our instrument and that in Mohr et al. (2013), such as the amount of acetic anhydride introduced into the instrument, IMR and SSQ pressures, and declustering settings in the quadrupole ion guides, all of which affect sensitivities of acetate CIMS significantly (Stark et al., 2012). The main reagent ions in IMR were shown to be acetic acidacetate clusters rather than acetate (Bertram et al., 2011), and the cluster distributions in IMR may depend on operated pressure in IMR and the amount of acetic anhydride introduced into the ion source. While declustering in SSQ helps the interpretation of recorded mass spectra, declustering also obscures a precise understanding of cluster distributions in IMR and hence accurate prediction of sensitivities in acetate CIMS. This result also emphasizes the importance of instrument calibrations in deriving concentration from acetate CIMS. We note that 3-nitrophenol (3-NP) is not usually present in the atmosphere (Harrison et al., 2005a). Thus, the average of the sensitivities of 2-NP and 4-NP was used for calculating concentrations of NP. DMNP was not calibrated in this study and we assumed the same sensitivity as determined for MNP.

The accuracies of nitrated phenols measurements by the CIMS are conservatively estimated to be around $40 \%$ for NP and $50 \%$ for other nitrated phenols, mainly arising from uncertainties in the concentration output of the LCU $(\sim 10 \%)$, uncertainties associated with calibration procedures $(\sim 5 \%)$, errors in high-resolution (HR) peak fittings to mass spectra (see above and Fig. S2), and the representativeness of the calibrated species to other isomers (0-30\% for NP and 0-40\% for other nitrated phenols). Assuming random errors in the observed ion counts follow a Poisson distribution, detection limits of nitrated phenols, i.e., concentrations with a signal to noise ratio $(S / N)$ of 3 , are calculated to be $0.1-0.3 \mathrm{ppt}$ for $1 \mathrm{~min}$ average data (Table 1). Following the discussions in Bertram et al. (2011), the measured background ion counts in ToF-CIMS drift over time and thus detection limits are more appropriately calculated as the concentrations at 3 times the standard deviation of the measurement background counts. The determined detection limits of nitrated phenols increase to the range of $0.3-0.5 \mathrm{ppt}$ based on this approach (Bertram et al., 2011) (Table 1).

\subsection{Other measurements}

Volatile organic compounds (VOCs), including hydrocarbons and oxygenates, were measured using an online gas chromatograph-mass spectrometer (GC-MS) (Gilman et al., 2013). A commercial proton transfer reaction time-of-flight mass spectrometer (PTR-TOF) (IONICON Analytik, Austria) was also deployed at the Horse Pool site to measure various VOC species (Warneke et al., 2015). Measurements of phenol, cresols, and dimethylphenols + ethylphenols (DMP) were accomplished using the PTR-TOF at $m / z$ 95.0491 $\left(\mathrm{C}_{6} \mathrm{H}_{6} \mathrm{OH}^{+}\right), m / z \quad 109.0648\left(\mathrm{C}_{7} \mathrm{H}_{8} \mathrm{OH}^{+}\right)$, and $m / z 123.0804$ $\left(\mathrm{C}_{8} \mathrm{H}_{10} \mathrm{OH}^{+}\right)$, respectively. An example of high-resolution peak fitting to $m / z 95$ in the mass spectra of the PTR-TOF is shown in Fig. S3. The sensitivities to these phenols are estimated here from the calibrated sensitivities of $\mathrm{m} / \mathrm{z} 93.0699$ (toluene), $m / z 107.0855$ (C8 aromatics), and $m / z 121.1012$ (C9 aromatics) and the ratio of proton transfer rate coefficients $(k)$ of the phenols versus the aromatic hydrocarbons (Cappellin et al., 2012) (see details in the Supplement). Considering the uncertainties in the rate coefficients $k$, the accuracies of the determined concentrations of phenols can be up to $50 \%$ (de Gouw and Warneke, 2007).

Measurements of $\mathrm{NO}_{3}$ and $\mathrm{N}_{2} \mathrm{O}_{5}$ were conducted by a cavity ring-down spectroscopy instrument (Dubé et al., 2006). $\mathrm{NO}_{x}\left(\mathrm{NO}+\mathrm{NO}_{2}\right), \mathrm{NO}_{y}$, and $\mathrm{O}_{3}$ were measured with 

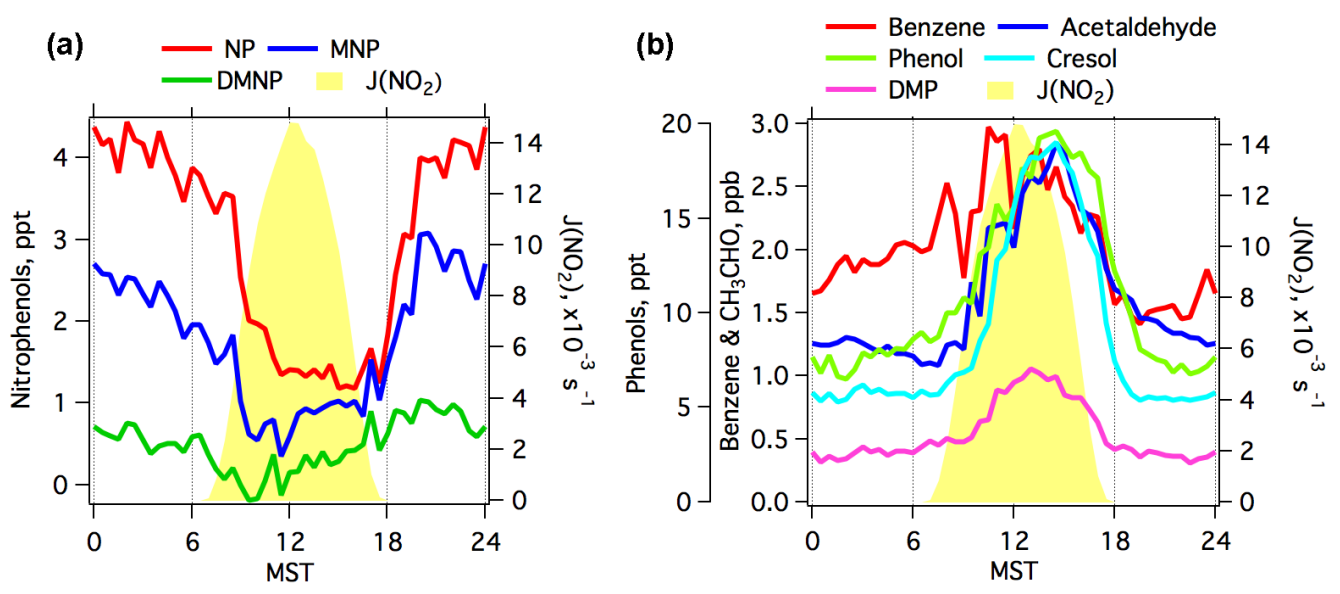

Figure 3. (a) Diurnal profiles of measured NP, MNP, and DMNP. (b) Diurnal profiles of benzene, acetaldehyde, phenol, cresol, and DMP. Photolysis frequencies of $\mathrm{NO}_{2}$ are shown in both (a) and (b) for reference.

another cavity ring-down spectroscopy instrument (Wild et al., 2014). Measurements of methane $\left(\mathrm{CH}_{4}\right)$ and carbon dioxide $\left(\mathrm{CO}_{2}\right)$ were performed with a commercial cavity ringdown spectrometry instrument (Picarro G2301). A pair of commercial spectral radiometers (Metcon Inc.) were used to measure photolysis frequencies of ozone and $\mathrm{NO}_{2}$.

\section{Results and discussions}

\subsection{Diurnal variations}

Measured diurnal profiles of NP, MNP, and DMNP during the UBWOS 2014 are shown in Fig. 3. Very strong diurnal variations in concentrations of these nitrated phenols were observed. Concentrations of nitrated phenols were higher at night and lower in the daytime. The ratios between the concentrations in the $2 \mathrm{~h}$ around midnight (23:00-01:00 MST) and in the $2 \mathrm{~h}$ around noon (11:00-13:00 MST) are 2.9, 3.9, and 4.7 for NP, MNP, and DMNP, respectively. This indicates that the substituted alkyl groups enhance the diurnal variations in nitrated phenols, either through larger source at night or stronger loss in the daytime.

Primary emissions of VOCs and $\mathrm{NO}_{x}$ at the Horse Pool site are predominantly due to oil and gas production activities, as the Horse Pool site is surrounded by oil and gas production wells. VOCs and $\mathrm{NO}_{x}$ emitted from nearby oil and gas wells led to periodic concentration spikes during the UBWOS campaigns (Warneke et al., 2014; Yuan et al., 2015). Figure 4 shows two types of episodes encountered during UBWOS 2014. The first was associated with high concentrations of methane and benzene, as an example of fugitive emissions from oil and gas wells. No enhancement of nitrated phenols was observed for the first emission episode. The second episode was associated with high concentrations of $\mathrm{NO}_{y}, \mathrm{NO}_{x}$, and $\mathrm{CO}_{2}$, as an example of either vehicular emissions or other fuel combustion activities related to oil and gas extractions (e.g., compressors, dehydrators, and pump jacks). High $\mathrm{NO}_{x} / \mathrm{NO}_{y}$ ratios $(0.96 \pm 0.01)$ indicate that a fresh combustion plume was encountered. We observed small enhancement of NP during the second emission episode. The enhancement ratio of $\mathrm{NP} / \mathrm{NO}_{y}$ in this plume is determined to be $4.6 \pm 0.7 \times 10^{-3} \mathrm{ppt} / \mathrm{ppb}$, which is comparable with the reported $\mathrm{NP} / \mathrm{NO}_{x}$ emission ratios $\left(1-50 \times 10^{-3} \mathrm{ppt} / \mathrm{ppb}\right)$ from gasoline and diesel vehicles (Inomata et al., 2013; Sekimoto et al., 2013). Using the obtained enhancement ratio of $\mathrm{NP} / \mathrm{NO}_{y}$, we determine that primary emissions from combustion sources only account for less than $2 \%$ of NP concentrations during UBWOS 2014. In addition to these primary sources, biomass burning was not observed in the UBWOS campaigns, based on the absence of any enhancement of biomass burning markers like acetonitrile. We conclude that primary emissions of nitrated phenols were not significant during UBWOS 2014.

In addition to primary emissions, secondary formation from oxidation of phenols is an important source for nitrated phenols (Harrison et al., 2005a). Phenol exhibited a concentration maximum in the afternoon (Fig. 3b). The diurnal profile of phenol is more similar to that of secondary acetaldehyde than that of primary emitted benzene. It suggests that secondary formation was the most important source of phenol. Substituted phenols (cresols and DMP) also had similar diurnal variations as phenol.

\subsection{Modeling analysis for NP}

\subsubsection{Box model results}

We will focus on NP to understand the budget of nitrated phenols, because NP had higher concentrations than the substituted nitrated phenols (MNP and DMNP) and there is more information on sources and sinks of NP in the literature. A series of zero-dimensional box model simulations on the formation of phenol and NP were conducted using the 

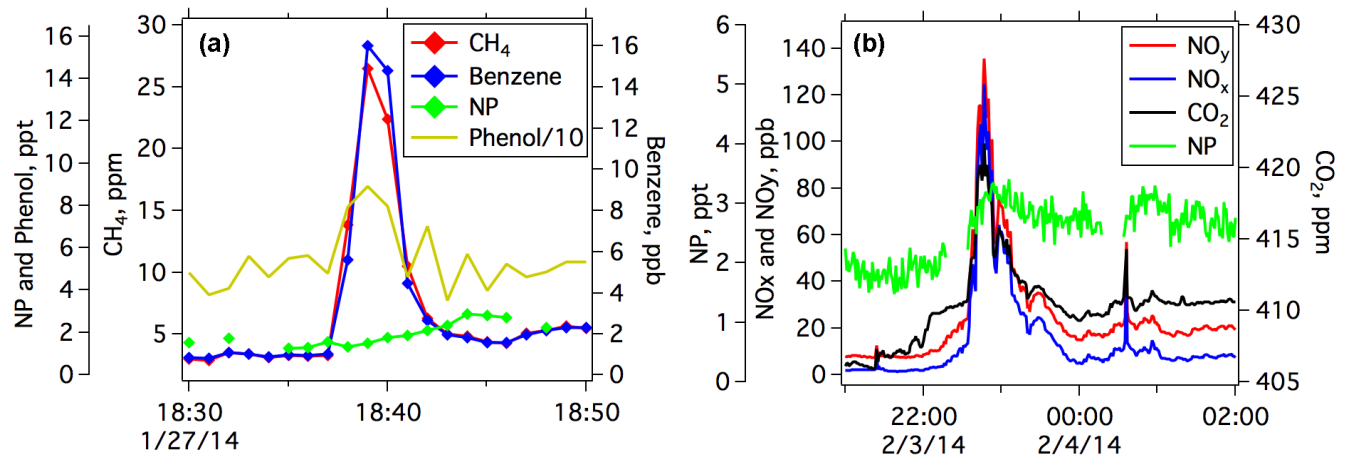

Figure 4. (a) An episode with high concentrations of methane and benzene on 27 January 2014 during UBWOS 2014. The source for this episode was fugitive emissions from oil and gas activities. (b) An episode with high concentrations of $\mathrm{NO}_{y}$ and $\mathrm{CO}_{2}$ on 3 February 2014 during UBWOS 2014. The source for this episode was fuel combustion (e.g., vehicle exhaust and/or other combustion sources for oil and gas extraction).

online AtChem tool (https://atchem.leeds.ac.uk). The MCM v3.2 (Jenkin et al., 2012) was used as the chemical mechanism in the box model. We note that ambient temperature $\left(-5 \pm 5^{\circ} \mathrm{C}\right)$ during UBWOS 2014 was much lower than the temperature (around $25^{\circ} \mathrm{C}$ ) at which rate constants of many reactions are usually measured. Rate constants as a function of temperature are only available for the reactions of $\mathrm{OH}$ radical with benzene and phenol among those shown in Fig. 1, and they were already included in the MCM v3.2. The model ran in a time-dependent mode and a $48 \mathrm{~h}$ spin-up time was applied in the box model. Measured concentrations of various hydrocarbons, $\mathrm{NO}_{x}, \mathrm{O}_{3}, \mathrm{NO}_{3}$, and photolysis frequencies (Table S2) were used as constraints in the box model. The simulation period of the model was chosen to be 1827 January, a period associated with several buildup episodes of ozone and other secondary products, with high measured concentrations of NP and without precipitation. Following previous box model studies (Yuan et al., 2015; Edwards et al., 2014), dilution and deposition processes were represented together using a diurnally varying first-order physical loss parameter in the box model. The physical loss rate at night $\left(5.8 \times 10^{-6} \mathrm{~s}^{-1}\right)$ was calculated from the decrease rate of NP concentration between 00:00 and 06:00, when the chemical loss was expected to be low (see Sect. 3.3.4). A higher physical loss rate $\left(2.0 \times 10^{-5} \mathrm{~s}^{-1}\right)$ during daytime was used to account for larger turbulent mixing during daytime (Edwards et al., 2014), which results in the decrease in concentrations of inert tracers in the afternoon, e.g., benzene (Fig. 3) and methane. Based on sensitivity tests of the box model, increase and decrease in the physical loss rate terms by a factor of 2 resulted in -48 and $+39 \%$ of changes in the modeled NP concentrations.

As shown in the introduction section, photolysis has been recognized as an important sink for nitrated phenols. However, the photolysis of NP (and other nitrated phenols) is not included in the MCM v3.2. We added the photolysis frequency of NP from Bardini (2006) (1.4\% of photolysis frequency of $\mathrm{NO}_{2}$ ) into the MCM v3.2 and this model run is referred to as the base simulation. Here, we assume that photolysis of NP produces 2-phenoxy biradicals and HONO, as proposed in Bejan et al. (2006) (Fig. 1, Route1). There are other possible chemical routes for photolysis of NP: producing phenoxy radicals $\left(\mathrm{C}_{6} \mathrm{H}_{5} \mathrm{O}\right)$ by losing $\mathrm{NO}_{2}$ (Route2 in Fig. 1) and producing nitrophenoxy radical by hydrogen abstraction (Route3 in Fig. 1). The simulation test in Fig. S4 indicates that the pathway forming $\mathrm{C}_{6} \mathrm{H}_{5} \mathrm{O}$ radicals and $\mathrm{NO}_{2}$ is an ineffective sink for NP, since $\mathrm{C}_{6} \mathrm{H}_{5} \mathrm{O}$ radical will reform NP by reacting with $\mathrm{NO}_{2}$. However, we cannot exclude that this pathway occurs along with that producing 2phenoxy biradicals and HONO. The photolysis frequency determined in Bardini (2006) based on concentration changes of 2-nitrophenol in a chamber may not include this pathway as well. As a result, attributing the photolysis rates determined in Bardini (2006) to other pathways other than Route2 is reasonable. The route producing nitrophenoxy radical will be discussed in Sect. 3.3.

The simulated results for phenol and NP from the base case of the box model are shown in Fig. 5. The modeled diurnal variations agreed reasonably well with the observation for both NP and phenol in the base simulation, except for the phenol nighttime levels that will be discussed below. Although modeled NP concentrations are higher than the measurements for both daytime and nighttime, the agreement between measurements and model results is still within their combined uncertainties.

The average measured concentrations of phenol at night are higher than $10 \mathrm{ppt}$, but the modeled phenol concentrations are usually less than $2 \mathrm{ppt}$. At night, the production of phenol from benzene oxidation halts, and the fast reaction with $\mathrm{NO}_{3}\left(2.8 \times 10^{-11} \mathrm{~cm}^{3}\right.$ molecule $\mathrm{s}^{-1} \mathrm{~s}^{-1}$ at $\left.298 \mathrm{~K}\right)$ removes phenol quickly (Fig. 7 and discussion in Sect. 3.2.3). Measured nighttime $\mathrm{NO}_{3}$ radicals were quite low during UBWOS $2014(1.4 \pm 2.4 \mathrm{ppt})$. As a check on the possible uncertainties in measurements of $\mathrm{NO}_{3}$ at these low levels, simu- 


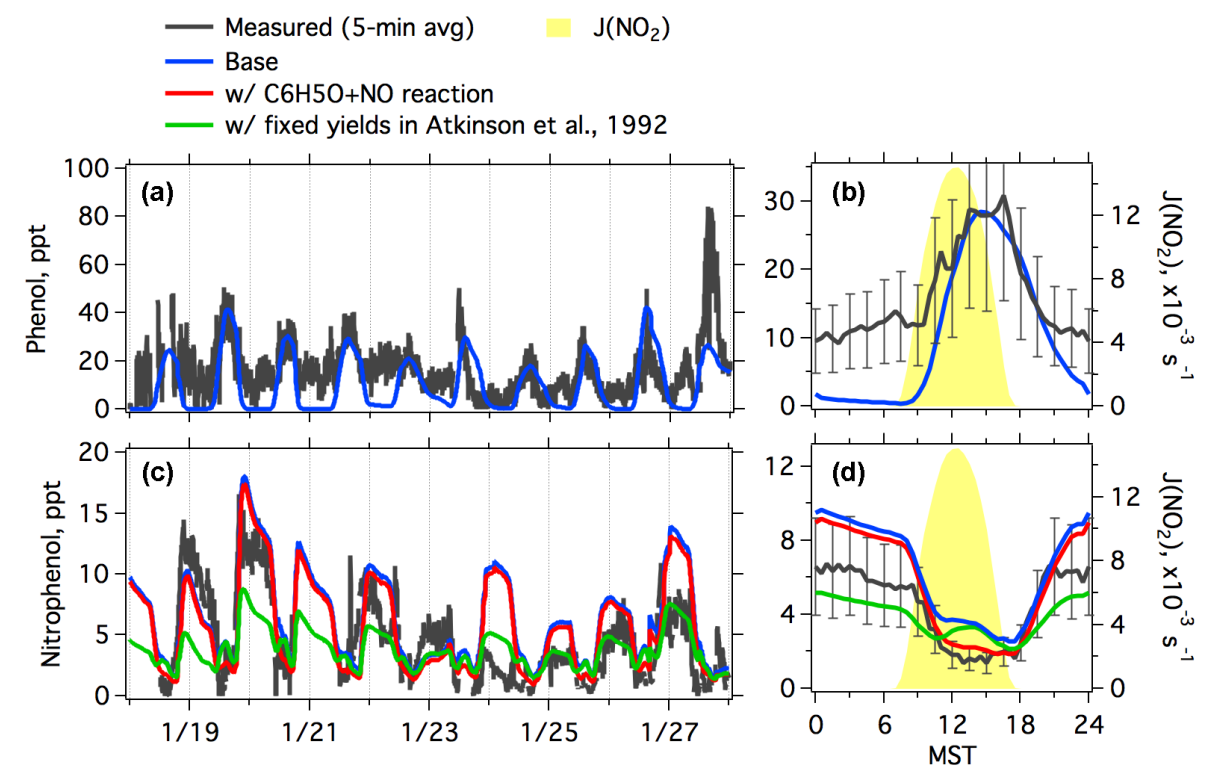

Figure 5. (a, c) Comparison of measured and modeled time series of phenol (a) and NP (c). (b, d) Diurnal profiles of measured and modeled concentrations of phenol (b) and NP (d). Photolysis frequencies of $\mathrm{NO}_{2}$ are shown in (b) and (d) for reference. Error bars in (b) and (d) indicate the accuracies of measured concentrations of phenol (50\%) and NP (40\%), respectively.

lations by varying $\mathrm{NO}_{3}$ concentrations by a factor of 2 result in little improvement for the modeled concentrations of phenol (Fig. S5). Another simulation using calculated $\mathrm{NO}_{3}$ concentrations from the equilibrium between $\mathrm{NO}_{3}$ and $\mathrm{N}_{2} \mathrm{O}_{5}$ (Fig. S5) also indicates that uncertainties in $\mathrm{NO}_{3}$ measurements cannot account for the discrepancies between measured and modeled phenol at night. The high phenol concentrations measured at night might be a result of primary emissions. Indeed, the measured phenol concentration was slightly enhanced in the plume with high methane concentrations (see Fig. 4a). However, a simulation using the measured phenol concentrations as a constraint in the box model predicted much higher NP concentrations than measurements (Fig. S4). Perhaps a more likely explanation for the enhanced phenol concentrations at night is that the measurements of phenol by PTR-TOF suffer from chemical interferences at night. Vinylfuran might be a candidate (Karl et al., 2007; Stockwell et al., 2015). Thus, the modeled concentrations of phenol shown in Fig. 5 will be used in the following discussions.

\subsection{2 $\mathrm{NO}_{2}$ dependence of NP yields}

As shown in Fig. 1, NP is generated from the reaction of $\mathrm{NO}_{2}$ with phenoxy radicals $\left(\mathrm{C}_{6} \mathrm{H}_{5} \mathrm{O} \cdot\right)$ (Berndt and Boge, 2003), which is an intermediate from the reactions of $\mathrm{OH}$ and $\mathrm{NO}_{3}$ radicals with phenol and the reaction of phenylperoxy radicals $\left(\mathrm{C}_{6} \mathrm{H}_{5} \mathrm{O}_{2}\right)$ with NO. In addition to $\mathrm{NO}_{2}, \mathrm{C}_{6} \mathrm{H}_{5} \mathrm{O} \cdot$ radicals also react with $\mathrm{NO}$ and $\mathrm{O}_{3}$ (Platz et al., 1998) (see Fig. 1). Thus, the yield of NP has been reported to depend on $\mathrm{NO}_{2}$ concentrations in the atmosphere (Berndt and Boge, 2003).

In the MCM v3.2, only the reactions of $\mathrm{C}_{6} \mathrm{H}_{5} \mathrm{O}$ radical with $\mathrm{O}_{3}$ and $\mathrm{NO}_{2}$ are included and here we added the reaction of $\mathrm{C}_{6} \mathrm{H}_{5} \mathrm{O}$ with $\mathrm{NO}\left(k=1.88 \times 10^{-12} \mathrm{~cm}^{3}\right.$ molecule $\left.^{-1} \mathrm{~s}^{-1}\right)$ for a new simulation. Compared to the base simulation, the modeled concentrations of NP are lower, especially for the period of 11:00-17:00, as the effective yield of NP is reduced (Fig. 5). The small enhancement during the period of 11:00-17:00 in NP concentrations from the base simulation is absent in the simulation with the reaction of $\mathrm{C}_{6} \mathrm{H}_{5} \mathrm{O}$ with NO. The variations in modeled NP concentrations in the daytime from the new simulation are in better agreement with the measurements (Fig. 5). This indicates that the reaction of NO and $\mathrm{C}_{6} \mathrm{H}_{5} \mathrm{O}$ radical should be considered to account for the $\mathrm{NO}_{2}$ dependence of NP formation.

Another simulation using fixed NP yields from phenol oxidation reported in Atkinson et al. (1992) (6.7\% for OH oxidation and $25.1 \%$ for $\mathrm{NO}_{3}$ oxidation) is also performed. This simulation neglects any dependence of NP yield from phenol oxidation on concentrations of $\mathrm{NO}_{2}, \mathrm{O}_{3}$ and NO. We observed lower concentrations during both the day and night compared to the base simulation (Fig. 5). However, the enhancement of modeled NP in the period of 11:00-17:00 is distinctly observed with the simulation using the fixed yields in Atkinson et al. (1992), which is in contrast to the lowest concentration in the afternoon from our observations. This, again, indicates there must be a dependence of NP yield from phenol oxidation on $\mathrm{NO}_{2}$ concentrations in the atmosphere. 
Table 2. Vapor pressure, enthalpy of evaporation ( $\left.\Delta H_{\mathrm{vap}}\right)$, and calculated concentration fractions in the particle phase $\left(F_{\mathrm{p}}\right)$ for several nitrated phenols.

\begin{tabular}{llll}
\hline Species & $\begin{array}{l}\text { Vapor pressure } \\
\text { at 298 K, Torr }\end{array}$ & $\begin{array}{l}\Delta H_{\mathrm{vap}}, \\
\mathrm{kJ} \mathrm{mol}^{-1} *\end{array}$ & $F_{\mathrm{p}}$ \\
\hline 2-NP & 0.20 & 53.1 & $1.1 \pm 0.9 \times 10^{-4}$ \\
4-NP & $1.4 \times 10^{-3}$ & 80.0 & $5.3 \pm 4.8 \times 10^{-2}$ \\
2,4-DNP & $8.4 \times 10^{-3}$ & 70.4 & $4.6 \pm 4.4 \times 10^{-3}$ \\
2,5-DNP & $1.2 \times 10^{-3}$ & 68.5 & $2.8 \pm 2.7 \times 10^{-3}$ \\
\hline
\end{tabular}

* Calculated from data in Schwarzenbach et al. (1988).

\subsubsection{Gas-particle partitioning of NP}

NP formed in the gas phase can partition into particles (Harrison et al., 2005a). Measurements in several studies demonstrated that 2-NP and MNP were mainly found in the gas phase (Herterich and Herrmann, 1990; Cecinato et al., 2005; Morville et al., 2006). However, the reported particle fractions of 4-NP and DNP exhibit a broad range in values: the particle fractions of 4-NP and DNP reported in Herterich and Herrmann (1990) were both lower than $15 \%$, whereas most of the concentrations of 4-NP (> 75\%) (Cecinato et al., 2005) and DNP (>95\%) (Morville et al., 2006) were detected in particles in these two studies.

The concentrations of NP and other nitrated phenols in particles were not measured in this study. We acknowledge that some fractions of nitrated phenols in particles may evaporate into gas phase in the heated inlets. If it holds true, the measured concentrations of nitrated phenols in this study would fall somewhere between concentrations in the gas phase and the total gas + particle concentrations. Here, the gas-particle partitioning of NP as a function of time was estimated using the equilibrium absorption partitioning theory (Pankow, 1994; Donahue et al., 2006) (see details in the SI), based upon pure-compound liquid vapor pressures of 2-NP and 4-NP (Schwarzenbach et al., 1988) (Table 2) and organic aerosol (OA) concentrations measured with an aerosol mass spectrometer (AMS). The dependence with temperature was accounted for using the Clausius-Clapeyron relationship with reported enthalpies of evaporation $\left(H_{\text {vap }}\right)$ (Schwarzenbach et al., 1988). Although vapor pressures from Schwarzenbach et al. (1988) might have significant uncertainties, Schwarzenbach et al. (1988) provided the only comprehensive measurements of sub-cooled liquid vapor pressures of nitrated phenols in the literature.

The calculated fractions in the particle phase $\left(F_{\mathrm{p}}\right)$ for 2-NP were generally very low (campaign average: $1.1 \pm 0.9 \times 10^{-4}$; max: $7.3 \times 10^{-4}$ ), whereas $F_{\mathrm{p}}$ for 4 -NP were higher (average: $0.053 \pm 0.048$; max: 0.38 ). The variability of the determined $F_{\mathrm{p}}$ values is the result of variations in both $\mathrm{OA}$ concentrations $\left(12.5 \pm 8.7 \mu \mathrm{g} \mathrm{m}^{-3}\right.$; min: $<1 \mu \mathrm{g} \mathrm{m}^{-3}$; max: $42.6 \mu \mathrm{g} \mathrm{m}^{-3}$ ) and ambient temperature $\left(-5 \pm 5^{\circ} \mathrm{C}\right.$; min: $-17^{\circ} \mathrm{C}$; max: $\left.10^{\circ} \mathrm{C}\right)$ during the campaign. The higher $F_{\mathrm{p}}$ for $4-\mathrm{NP}$ is expected, as $4-\mathrm{NP}\left(1.4 \times 10^{-3}\right.$ Torr at $298 \mathrm{~K}$ ) has much lower vapor pressure than 2-NP $(0.20$ Torr at $298 \mathrm{~K})$ (Table 2). In addition to absorption, partitioning of NP into the aqueous phase of particles is another possible pathway affecting $F_{\mathrm{p}}$. This mechanism is estimated using Henry's law constants (Sander, 2015) and the liquid water content (LWC) $\left(8.4 \pm 7.5 \mu \mathrm{g} \mathrm{m}^{-3}\right)$ in aerosol determined using the ISORROPIA model (Fountoukis and Nenes, 2007). The estimated $F_{\mathrm{p}}$ values based on aqueous-phase partitioning for 2-NP $\left(1.3 \times 10^{-7}\right)$ and 4-NP $\left(3.0 \times 10^{-5}\right)$ are both much lower than $F_{\mathrm{p}}$ estimated from the equilibrium absorption partitioning theory, indicating partitioning of NP into the particle aqueous phase was not important during UBWOS 2014.

The gas-particle partitioning of 2-NP and 4-NP determined above was incorporated into the box model by constraining the estimated $F_{\mathrm{p}}$ in the determination of gasparticle mass transport rates. The mass transport rates $\left(R_{\text {in }}\right.$ and $R_{\text {out }}$ ) of a species into and out of particles with radius $r$ are approximated by Jacob (2000):

$R_{\text {in }}=\left(\frac{r}{D_{\mathrm{g}}}+\frac{4}{v \alpha}\right)^{-1} A \times c_{\mathrm{g}}=\frac{1}{\tau} \times c_{\mathrm{g}}$,
$R_{\text {out }}=\left(\frac{r}{D_{\mathrm{g}}}+\frac{4}{v \alpha}\right)^{-1} A \times \frac{c_{\mathrm{p}}}{K_{\mathrm{ep}}}=\frac{1}{\tau} \times \frac{c_{\mathrm{p}}}{K_{\mathrm{ep}}}$,

where $c_{\mathrm{g}}$ and $c_{\mathrm{p}}$ are concentrations of the species in the gas and particle phase. $D_{\mathrm{g}}$ is the gas-phase molecular diffusion coefficient $\left(\mathrm{m}^{2} \mathrm{~s}^{-1}\right), v$ is the mean molecular speed $\left(\mathrm{m} \mathrm{s}^{-1}\right)$, and $\alpha$ is the mass accommodation coefficient. $A$ is the aerosol surface area per unit volume of air $\left(\mathrm{m}^{2} \mathrm{~m}^{-3}\right) . K_{\mathrm{ep}}$ is the equilibrium constant, i.e., $c_{\mathrm{p}} / c_{\mathrm{g}}$, or $F_{\mathrm{p}} /\left(1-F_{\mathrm{p}}\right)$. The characteristic timescale of mass transfer $(\tau)$ is estimated to be on the order of minutes for particles in the troposphere (Bowman et al., 1997; Jacob, 2000). Thus, rather than determining the characteristic timescale explicitly, we assume that the equilibrium is maintained at each model step ( $\tau=5 \mathrm{~min})$. After entering into particles, no further reaction of NP was prescribed in the model. The modeled diurnal profiles of NP associated with the inclusion of gas-particle partitioning are shown in Fig. 6. Compared to the base simulation, the modeled NP concentrations in the gas phase using the estimated $F_{\mathrm{p}}$ from 4-NP are lower (4-8\%) for most of the day and slightly higher $(2-3 \%)$ in the morning, when NP concentrations decreased quickly. Since the predicted $F_{\mathrm{p}}$ from 2NP is very small, the modeled NP concentrations in the gas phase using the estimates from 2-NP were almost identical to the base simulation. In contrast with the modeled concentrations of NP in the gas phase, the modeled total concentrations of NP in gas and particle phase are consistently higher than the base simulation that does not consider gas-particle partitioning. In summary, we observe relatively small changes of the modeled gaseous NP concentrations after the inclusion of gas-particle partitioning in the box model. Further measure- 


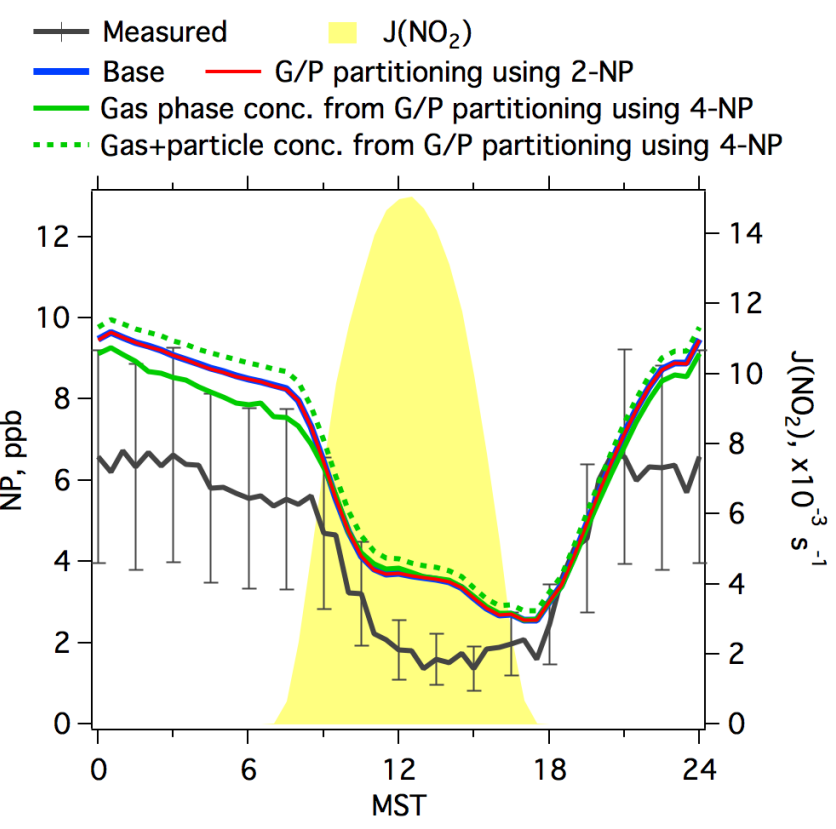

Figure 6. Diurnal profiles of measured and modeled concentrations of NP from the base simulation and the simulations considering gas-particle partitioning. Photolysis frequencies of $\mathrm{NO}_{2}$ are shown for reference. Error bars indicate the accuracies of measured concentrations of NP $(40 \%)$.

ments of the gas-particle partitioning of nitrated phenols are needed to explain the variety of $F_{\mathrm{p}}$ values observed in different studies and/or the potential differences between measurements and prediction from the equilibrium absorption partitioning model.

\subsubsection{Budget analysis of phenol and nitrophenol}

Diurnal profiles of formation and loss rates derived from the base simulation of the box model for both phenol and NP are shown in Fig. 7. Production of phenol only occurs in the daytime from $\mathrm{OH}$ oxidation of benzene. The magnitudes of losses of phenol due to $\mathrm{OH}$ oxidation $\left(21 \mathrm{ppt}^{-1} \mathrm{y}^{-1}\right)$ and $\mathrm{NO}_{3}$ oxidation (19 ppt day ${ }^{-1}$ ) are comparable on a daily basis. From morning to afternoon (08:00-15:00), production of phenol is larger than the losses, resulting in continuous growth of phenol concentrations in this period. After 15:00, the losses start to surpass the production and phenol concentrations decrease quickly. With fast reduction of phenol concentrations in the evening, phenol loss from the reaction with $\mathrm{NO}_{3}$ mainly occurred before midnight.

As shown in Fig. 7, NP is produced during both daytime and night, with more production in the daytime. As mentioned earlier, the only formation pathway of NP is from the reaction of phenoxy radicals $\left(\mathrm{C}_{6} \mathrm{H}_{5} \mathrm{O}\right)$ with $\mathrm{NO}_{2}$, so the contribution from different pathways to NP formation can be derived from source analysis of $\mathrm{C}_{6} \mathrm{H}_{5} \mathrm{O}$ radicals (Fig. 7c). The production of $\mathrm{C}_{6} \mathrm{H}_{5} \mathrm{O}$ radicals is dominated by the reaction of
$\mathrm{C}_{6} \mathrm{H}_{5} \mathrm{O}_{2}$ radicals with $\mathrm{NO}$ during daytime $(71 \%$ for $24 \mathrm{~h}$ average) and the reaction of phenol with $\mathrm{NO}_{3}$ radicals at night ( $27 \%$ for $24 \mathrm{~h}$ average). There are several sources contributing to the formation of $\mathrm{C}_{6} \mathrm{H}_{5} \mathrm{O}_{2}$ radicals in the MCM, including photolysis of benzaldehyde and peroxybenzoic acid, $\mathrm{OH}$ oxidation of benzoic acid and phenyl hydroperoxide, and degradations of other radicals (e.g., phenylperoxyacyl radical $\mathrm{C}_{6} \mathrm{H}_{5} \mathrm{CO}_{3}$ ), suggesting a wide range of aromatic compounds as the precursors of NP in the daytime. The reaction of phenol with $\mathrm{OH}$ radicals only accounts for a small fraction of the production of $\mathrm{C}_{6} \mathrm{H}_{5} \mathrm{O}$ radicals ( $2 \%$ for $24 \mathrm{~h}$ average), due to the small yield of NP $(6 \%)$ from the reaction of $\mathrm{OH}$ with phenol in the MCM. This indicates that phenol is not an important precursor for NP during daytime. The destruction of NP is mainly due to photolysis (17 ppt day $\left.{ }^{-1}\right)$, with some contributions from $\mathrm{NO}_{3}$ reaction $\left(1.7 \mathrm{ppt}_{\text {day }}{ }^{-1}\right)$. The reaction with $\mathrm{OH}$ radicals is not important for the losses of NP in UBWOS 2014. Dilution/deposition processes account for $20 \%$ of the total loss of NP in the box model. Our results are consistent with a previous proposal on photolysis as the dominant chemical loss pathway for nitrated phenols (Bejan et al., 2007). Based on the conditions at the Horse Pool site, the lifetime of NP due to photolysis at noontime is calculated to be $\sim 80 \mathrm{~min}$. As the result of the short lifetime of NP during daytime, the production $\left(23.6 \mathrm{ppt} \mathrm{day}^{-1}\right)$ and loss rates (23.1 ppt day ${ }^{-1}$ ) of NP maintain a balanced budget of NP on a daily basis. The inclusion of the reaction of phenoxy radicals $\left(\mathrm{C}_{6} \mathrm{H}_{5} \mathrm{O}\right)$ with NO discussed in Sect. 3.2.2 would mainly affect the NP budget at midday, with smaller production and loss in this period.

The different diurnal variations in production and loss rates of NP explain the measured diurnal profile of NP concentrations shown in Fig. 3. The increase in loss rates from photolysis result in the quick decline of NP concentrations in the morning. The formation of $\mathrm{NP}$ from $\mathrm{NO}_{3}$ oxidation of phenol in the evening exceeds the destruction of NP, which accounts for the enhancement of NP in this period. The formation and loss rates of NP are comparable in the afternoon and relatively constant concentrations of NP were observed.

A previous study showed that photolysis of nitrated phenols contributes to HONO formation (Bejan et al., 2006). If we assume photolysis of nitrated phenols at rates of $1.4 \% \times \mathrm{J}\left(\mathrm{NO}_{2}\right)$ yields $\mathrm{HONO}$ at a $100 \%$ yield (upper limit), photolysis of NP, MNP, and DMNP together accounted for a formation rate of $\mathrm{HONO}$ of $1.5 \pm 1.9 \mathrm{ppth}^{-1}$ around noontime (09:00-15:00) during UBWOS 2014. This photolysis source would increase the steady state concentrations of HONO by $0.5 \mathrm{ppt}$ in early morning (07:00-08:30) and $0.2 \mathrm{ppt}$ during the noontime period (09:00-15:00), which are only small fractions of measured HONO concentrations (50 100 ppt) during UBWOS 2014 (Edwards et al., 2014). 


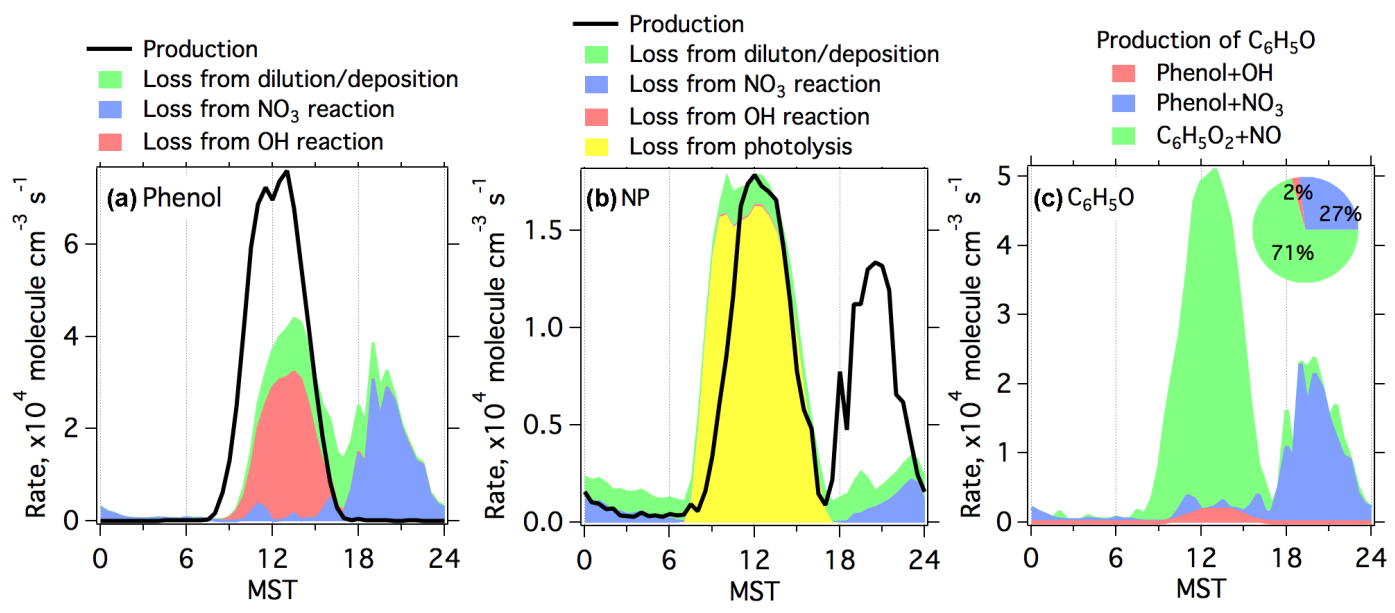

Figure 7. Diurnal profiles of production and loss rates from different pathways for phenol (a) and NP (b) derived from the base simulation of the box model. (c) Diurnal profiles of production rates from different pathways for $\mathrm{C}_{6} \mathrm{H}_{5} \mathrm{O}$ radicals. The inserted pie chart in (c) shows contributions from three different pathways to formation of $\mathrm{C}_{6} \mathrm{H}_{5} \mathrm{O}$ radicals on a daily basis.

\subsection{Dinitrophenol}

Further oxidation of NP in the presence of $\mathrm{NO}_{x}$ produces DNP. The measured time series of DNP in 18-22 January is shown in Fig. 8. A similar diurnal profile was observed for DNP as other nitrated phenols, with higher concentrations at night and lower in the daytime. We also notice that the peak time of DNP concentrations at night was somewhat later than $\mathrm{NP}$, consistent with further oxidation of NP as the source of DNP.

In the MCM v3.2, reactions of NP with $\mathrm{OH}$ or $\mathrm{NO}_{3}$ radicals generate nitrophenoxy radicals $\left(\mathrm{NO}_{2} \mathrm{C}_{6} \mathrm{H}_{5} \mathrm{O} \cdot\right)$, which react further with $\mathrm{NO}_{2}$ to form DNP. Here, we assume DNP has the same photolysis rate as NP (1.4\% of photolysis frequency of $\left.\mathrm{NO}_{2}\right)($ Bardini, 2006) and we added the photolysis into the MCM v3.2. The simulated concentrations of DNP from the box model are also displayed in Fig. 8. The agreement between measurements and simulation is quite good from the base simulation. DNP has also been observed in the particle phase at significant fractions (Morville et al., 2006). Using the equilibrium absorption partitioning theory described in Sect. 3.2.3 and vapor pressures of two different DNP isomers (2,4-DNP and 2,5-DNP) (Table 2), we incorporated the calculated particle fractions of DNP (Table 2) into the box model as a sensitivity simulation. The predicted DNP concentrations from this simulation are around 5\% lower than the base simulation at night. Considering the limited information on DNP formation, the agreement between measured and modeled concentrations of DNP from both simulations is encouraging. This degree of agreement implies that DNP concentrations measured in UBWOS 2014 are explainable by known chemical reactions in the gas phase.

As described in Sect. 3.2, photolysis is the dominant sink for NP and box model results indicate that photolysis of NP may not generate phenoxy radical (by losing $\mathrm{NO}_{2}$ ). The other

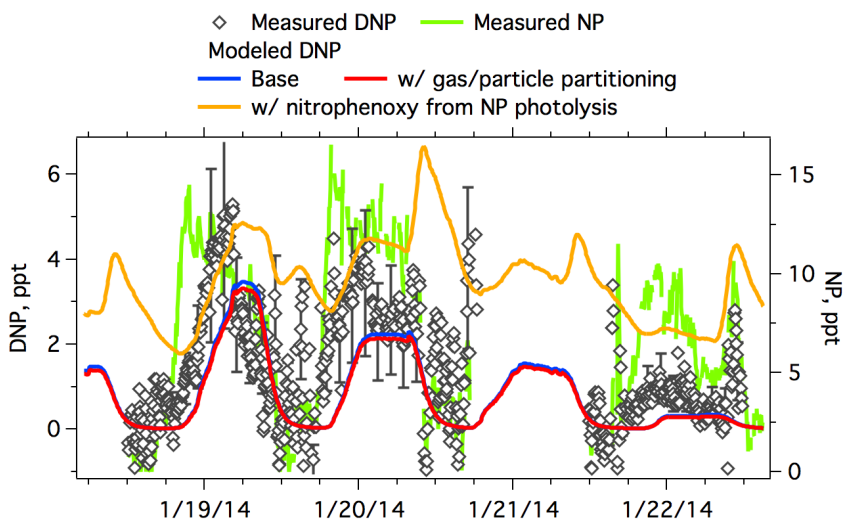

Figure 8. Comparison of measured and modeled time series of DNP. Measured time series of NP is also shown for comparison. Error bars indicate the accuracies of measured DNP concentrations $(50 \%)$.

possible product from photolysis of NP is nitrophenoxy radical (Fig. 1, Route 3), which would act as a secondary source of DNP. This assumption is evaluated as a new simulation. The simulation predicted concentration peaks of DNP in the morning (the orange line in Fig. 8), which are not observed in our measurements. Thus, we exclude nitrophenoxy radical as the main products of photolysis of NP. However, the product and exact chemical mechanisms for photolysis of NP remain unclear and thus the photolysis of NP warrants further detailed studies.

\subsection{Non-gas-phase reactions}

The box model only considers gas-phase reactions that produce nitrated phenols. In addition to gas-phase reactions, aqueous reactions in particles and heterogeneous reactions 


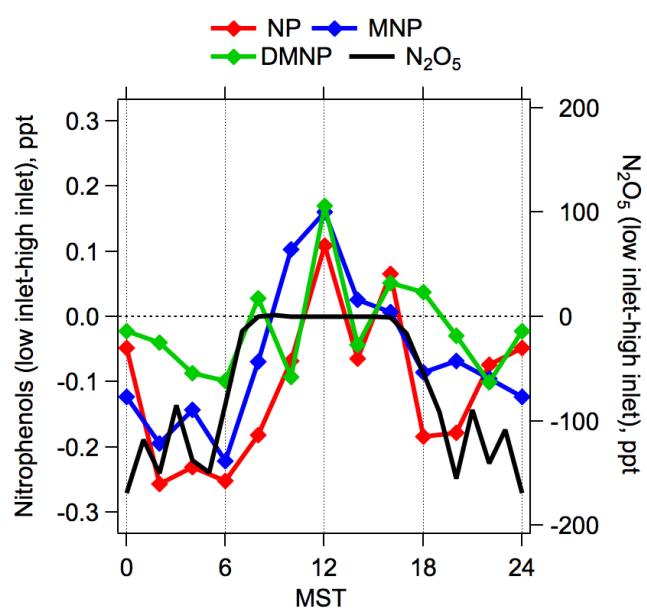

Figure 9. Diurnal profiles of vertical gradients for nitrated phenols measured in 22 January-1 February. The measured vertical gradient of $\mathrm{N}_{2} \mathrm{O}_{5}$ measured in 6-14 February is also shown for comparison.

are other potential sources of nitrated phenols (Harrison et al., 2005a). As shown in Sect. 3.2.3, using chemical compositions of aerosol at the Horse Pool site and the ISORROPIA model (Fountoukis and Nenes, 2007), the LWC in aerosol during UBWOS 2014 was estimated to be $8.4 \pm 7.5 \mu \mathrm{g} \mathrm{m}^{-3}$ (whole campaign average), or $8.4 \pm 7.5 \times 10^{-12}$ expressed as the volume fraction. Based on the box modeling results in Harrison et al. (2005b), aqueous reactions contribute less than $2 \%$ of NP production at $3 \times 10^{-9}$ volume fraction LWC. Thus, aqueous reactions in UBWOS 2014 should not be a significant source for nitrated phenols compared to gasphase reactions.

The Uintah Basin was covered by snow during UBWOS 2014. The importance of heterogeneous reactions on the snow surface to formation of nitrated phenols is evaluated using measurements of the vertical gradients of these species. Here, the concentration gradient is defined as the concentrations measured at $18.5 \mathrm{~m}$ subtracted from those measured at $1 \mathrm{~m}$. As shown in Fig. 9, we observed negative concentration gradients for nitrated phenols at night, indicating that deposition was playing a role and consequently ground snow was a net sink for nitrated phenols at night. A previous study suggested heterogeneous reaction of $\mathrm{N}_{2} \mathrm{O}_{5}$ with phenol in the aqueous phase produces NP (Heal et al., 2007). Strong deposition of $\mathrm{N}_{2} \mathrm{O}_{5}$ to the snow surface was observed at night during UBWOS 2014, but as discussed no production of nitrated phenols near the snow surface was detected at night (Fig. 9). The vertical gradients for nitrated phenols in the daytime fluctuated around zero with large variations, which might be a result of their low concentrations during daytime. The analysis of vertical gradients implies that heterogeneous reactions on snow surface may not be important for formation of nitrated phenols in the atmosphere during UBWOS 2014.

\section{Conclusions}

In this study, nitrated phenols in the gas phase were measured using an online acetate ToF-CIMS in an oil and gas production region during winter. Strong diurnal profiles were observed for nitrated phenols, with concentration maxima at night. As the dominant sink for nitrated phenols, photolysis accounted for lower concentrations of nitrated phenols during daytime. We determined that the photolysis of nitrated phenols was not an important source of HONO during UBWOS 2014. Based on box model results, NP was mainly formed in the daytime (73\%) from a wide range of precursors, with significant contribution from the reaction of phenol with $\mathrm{NO}_{3}$ radicals at night $(27 \%)$. Box model results also indicated that gas-phase oxidation of aromatics was able to explain the measured concentrations of NP and DNP. We demonstrated that box model results provided valuable information on the detailed chemical mechanisms in the formation and destruction of NP, e.g., the $\mathrm{NO}_{2}$ dependence of NP yields from phenol oxidations and chemical products of NP photolysis. We determined that aqueous-phase reactions and heterogeneous reactions were minor sources of nitrated phenols in this study. Although the data set of nitrated phenols was collected in an oil and gas production region, the chemistry in secondary formation of nitrated phenols and the dynamics of the budget of nitrated phenols in other regions, e.g., urban areas, should behave similarly to those shown in this study.

Biomass burning activity did not affect the UBWOS 2014 measurements, and the concentrations of phenols and nitrated phenols were mainly from oxidations of aromatics in the atmosphere. The measurements during UBWOS 2014 provided a great opportunity to study secondary formation of nitrated phenols in the absence of other confounding sources. The UBWOS 2014 campaign also represented the first coincident and high-time-resolution measurements of aromatic hydrocarbons, phenols, and nitrated phenols in ambient air. The measurements of phenol and nitrated phenols provided a better understanding of their sources, budgets, and roles in atmospheric chemistry and for the evaluation of the oxidation mechanisms of aromatics. This is achieved by the emergence of the new ToF-CIMS and PTR-TOF techniques. We envision that these techniques will provide the ability to detect many other intermediate compounds in the atmosphere and that the measurements will advance the understanding of atmospheric oxidation processes.

\section{The Supplement related to this article is available online at doi:10.5194/acp-16-2139-2016-supplement.}

Acknowledgements. The Uintah Basin Winter Ozone Studies were a joint project led and coordinated by the Utah Department of Environmental Quality (UDEQ) and supported by the Uintah Impact 
Mitigation Special Service District (UIMSSD), the Bureau of Land Management (BLM), the Environmental Protection Agency (EPA), and Utah State University. This work was funded in part by the Western Energy Alliance, and NOAA's Atmospheric Chemistry, Climate and Carbon Cycle program. We thank Questar Energy Products for site preparation and support. Chemical compositions of aerosol were provided by Tim Bates and James Johnson from NOAA Pacific Marine Environmental Laboratory (PMEL) and the Joint Institute for the Study of the Atmosphere and Ocean (JISAO) at the University of Washington.

Edited by: J. Collett

\section{References}

Atkinson, R., Aschmann, S. M., and Arey, J.: Reactions of hydroxyl and nitrogen trioxide radicals with phenol, cresols, and 2-nitrophenol at $296 \pm 2 \mathrm{~K}$, Environ. Sci. Technol., 26, 13971403, doi:10.1021/es00031a018, 1992.

Bardini, P.: Atmospheric Chemistry of Dimethylphenols \& Nitrophenols, PhD, University College Cork, Corcaigh, 1-156, 2006.

Bartmess, J. E.: Negative Ion Energetics Data, NIST Chemistry WebBook, NIST Standard Reference Database Number 69, edited by: Linstrom, P. J. and Mallard, W. G., National Institute of Standards and Technology, Gaithersburg MD, 20899, available at: http://webbook.nist.gov, last access: 28 August 2015.

Bejan, I., Abd El Aal, Y., Barnes, I., Benter, T., Bohn, B., Wiesen, P., and Kleffmann, J.: The photolysis of ortho-nitrophenols: a new gas phase source of HONO, Phys. Chem. Chem. Phys., 8, 2028 2035, 2006.

Bejan, I., Barnes, I., Olariu, R., Zhou, S., Wiesen, P., and Benter, T.: Investigations on the gas-phase photolysis and $\mathrm{OH}$ radical kinetics of methyl-2-nitrophenols, Phys. Chem. Chem. Phys., 9, 5686-5692, doi:10.1039/B709464G, 2007.

Bejan, I., Duncianu, M., Olariu, R., Barnes, I., Seakins, P. W., and Wiesen, P.: Kinetic Study of the Gas-Phase Reactions of Chlorine Atoms with 2-Chlorophenol, 2-Nitrophenol, and Four Methyl2-nitrophenol Isomers, The J. Phys. Chem. A, 119, 4735-4745, doi:10.1021/acs.jpca.5b02392, 2015.

Berndt, T. and Boge, O.: Gas-phase reaction of $\mathrm{OH}$ radicals with phenol, Phys. Chem. Chem. Phys., 5, 342-350, doi:10.1039/B208187C, 2003.

Bertram, T. H., Kimmel, J. R., Crisp, T. A., Ryder, O. S., Yatavelli, R. L. N., Thornton, J. A., Cubison, M. J., Gonin, M., and Worsnop, D. R.: A field-deployable, chemical ionization timeof-flight mass spectrometer, Atmos. Meas. Tech., 4, 1471-1479, doi:10.5194/amt-4-1471-2011, 2011.

Bolzacchini, E., Bruschi, M., Hjorth, J., Meinardi, S., Orlandi, M., Rindone, B., and Rosenbohm, E.: Gas-Phase Reaction of Phenol with $\mathrm{NO}_{3}$, Environ. Sci. Technol., 35, 1791-1797, doi:10.1021/es001290m, 2001.

Bowman, F. M., Odum, J. R., Seinfeld, J. H., and Pandis, S. N.: Mathematical model for gas-particle partitioning of secondary organic aerosols, Atmos. Environ., 31, 3921-3931, doi:10.1016/S1352-2310(97)00245-8, 1997.

Brophy, P. and Farmer, D. K.: A switchable reagent ion high resolution time-of-flight chemical ionization mass spectrometer for real-time measurement of gas phase oxidized species: character- ization from the 2013 southern oxidant and aerosol study, Atmos. Meas. Tech., 8, 2945-2959, doi:10.5194/amt-8-2945-2015, 2015.

Cappellin, L., Karl, T., Probst, M., Ismailova, O., Winkler, P. M., Soukoulis, C., Aprea, E., Mark, T. D., Gasperi, F., and Biasioli, F.: On quantitative determination of volatile organic compound concentrations using proton transfer reaction time-offlight mass spectrometry, Environ. Sci. Technol., 46, 2283-2290, doi:10.1021/es203985t, 2012.

Caralp, F., Foucher, V., Lesclaux, R., J. Wallington, T., and D. Hurley, M.: Atmospheric chemistry of benzaldehyde: UV absorption spectrum and reaction kinetics and mechanisms of the C6H5C(O)O2 radical, Phys. Chem. Chem. Phys., 1, 3509-3517, doi:10.1039/A903088C, 1999.

Cecinato, A., Di Palo, V., Pomata, D., Tomasi Scianò, M. C., and Possanzini, M.: Measurement of phase-distributed nitrophenols in Rome ambient air, Chemosphere, 59, 679-683, doi:10.1016/j.chemosphere.2004.10.045, 2005.

Chen, J., Wenger, J. C., and Venables, D. S.: Near-Ultraviolet Absorption Cross Sections of Nitrophenols and Their Potential Influence on Tropospheric Oxidation Capacity, The J. Phys. Chem. A, 115, 12235-12242, doi:10.1021/jp206929r, 2011.

Cheng, S.-B., Zhou, C.-H., Yin, H.-M., Sun, J.-L., and Han, K.-L.: $\mathrm{OH}$ produced from o-nitrophenol photolysis: A combined experimental and theoretical investigation, The Journal of Chemical Physics, 130, 234311, doi:10.1063/1.3152635, 2009.

Corbin, J. C., Othman, A., D. Allan, J., R. Worsnop, D., D. Haskins, J., Sierau, B., Lohmann, U., and A. Mensah, A.: Peak-fitting and integration imprecision in the Aerodyne aerosol mass spectrometer: effects of mass accuracy on location-constrained fits, Atmos. Meas. Tech., 8, 4615-4636, doi:10.5194/amt-8-4615-2015, 2015.

Cubison, M. J. and Jimenez, J. L.: Statistical precision of the intensities retrieved from constrained fitting of overlapping peaks in high-resolution mass spectra, Atmos. Meas. Tech., 8, 23332345, doi:10.5194/amt-8-2333-2015, 2015.

de Gouw, J. and Warneke, C.: Measurements of volatile organic compounds in the earth's atmosphere using proton-transferreaction mass spectrometry, Mass Spectrom. Rev., 26, 223-257, 2007.

Delhomme, O., Morville, S., and Millet, M.: Seasonal and diurnal variations of atmospheric concentrations of phenols and nitrophenols measured in the Strasbourg area, France, Atmospheric Pollution Research, 16-22, doi:10.5094/APR.2010.003, 2010.

Desyaterik, Y., Sun, Y., Shen, X., Lee, T., Wang, X., Wang, T., and Collett, J. L.: Speciation of "brown" carbon in cloud water impacted by agricultural biomass burning in eastern China, J. Geophys. Res.-Atmos., 118, 7389-7399, doi:10.1002/jgrd.50561, 2013.

Donahue, N. M., Robinson, A. L., Stanier, C. O., and Pandis, S. N.: Coupled Partitioning, Dilution, and Chemical Aging of Semivolatile Organics, Environ. Sci. Technol., 40, 2635-2643, doi:10.1021/es052297c, 2006.

Dubé, W. P., Brown, S. S., Osthoff, H. D., Nunley, M. R., Ciciora, S. J., Paris, M. W., McLaughlin, R. J., and Ravishankara, A. R.: Aircraft instrument for simultaneous, in situ measurement of $\mathrm{NO}_{3}$ and $\mathrm{N}_{2} \mathrm{O}_{5}$ via pulsed cavity ring-down spectroscopy, Rev. Sci. Instrum., 77, 034101, doi:10.1063/1.2176058, 2006. 
Edwards, P. M., Brown, S. S., Roberts, J. M., Ahmadov, R., Banta, R. M., deGouw, J. A., Dube, W. P., Field, R. A., Flynn, J. H., Gilman, J. B., Graus, M., Helmig, D., Koss, A., Langford, A. O., Lefer, B. L., Lerner, B. M., Li, R., Li, S. M., McKeen, S. A., Murphy, S. M., Parrish, D. D., Senff, C. J., Soltis, J., Stutz, J., Sweeney, C., Thompson, C. R., Trainer, M. K., Tsai, C., Veres, P. R., Washenfelder, R. A., Warneke, C., Wild, R. J., Young, C. J., Yuan, B., and Zamora, R.: High winter ozone pollution from carbonyl photolysis in an oil and gas basin, Nature, 514, 351354, doi:10.1038/nature13767, 2014.

Fernandez, P., Grifoll, M., Solanas, A. M., Bayona, J. M., and Albaiges, J.: Bioassay-directed chemical analysis of genotoxic components in coastal sediments, Environ. Sci. Technol., 26, 817-829, doi:10.1021/es00028a024, 1992.

Fountoukis, C. and Nenes, A.: ISORROPIA II: a computationally efficient thermodynamic equilibrium model for $\mathrm{K}^{+}$. $\mathrm{Ca}^{2+}-\mathrm{Mg}^{2+}-\mathrm{NH}^{4+}-\mathrm{Na}^{+}-\mathrm{SO}_{4}^{2-}-\mathrm{NO}_{3}^{-}-\mathrm{Cl}^{-}-\mathrm{H}_{2} \mathrm{O}$ aerosols, Atmos. Chem. Phys., 7, 4639-4659, doi:10.5194/acp-7-4639-2007, 2007.

Gilman, J. B., Lerner, B. M., Kuster, W. C., and de Gouw, J. A.: Source signature of volatile organic compounds from oil and natural gas operations in northeastern Colorado, Environ. Sci. Technol., 47, 1297-1305, 10.1021/es304119a, 2013.

Harrison, M. A. J., Barra, S., Borghesi, D., Vione, D., Arsene, C., and Iulian Olariu, R.: Nitrated phenols in the atmosphere: a review, Atmos. Environ., 39, 231-248, doi:10.1016/j.atmosenv.2004.09.044, 2005a.

Harrison, M. A. J., Heal, M. R., and Cape, J. N.: Evaluation of the pathways of tropospheric nitrophenol formation from benzene and phenol using a multiphase model, Atmos. Chem. Phys., 5, 1679-1695, doi:10.5194/acp-5-1679-2005, 2005b.

Heal, M. R., Harrison, M. A. J., and Neil Cape, J.: Aqueous-phase nitration of phenol by $\mathrm{N}_{2} \mathrm{O}_{5}$ and $\mathrm{ClNO}_{2}$, Atmos. Environ., 41, 3515-3520, doi:10.1016/j.atmosenv.2007.02.003, 2007.

Herterich, R. and Herrmann, R.: Comparing the distribution of nitrated phenols in the atmosphere of two German hill sites, Environ. Technol., 11, 961-972, doi:10.1080/09593339009384948, 1990.

Inomata, S., Tanimoto, H., Fujitani, Y., Sekimoto, K., Sato, K., Fushimi, A., Yamada, H., Hori, S., Kumazawa, Y., Shimono, A., and Hikida, T.: On-line measurements of gaseous nitroorganic compounds in diesel vehicle exhaust by proton-transferreaction mass spectrometry, Atmos. Environ., 73, 195-203, doi:10.1016/j.atmosenv.2013.03.035, 2013.

Jacob, D. J.: Heterogeneous chemistry and tropospheric ozone, Atmos. Environ., 34, 2131-2159, doi:10.1016/S13522310(99)00462-8, 2000.

Jenkin, M. E., Saunders, S. M., Wagner, V., and Pilling, M. J.: Protocol for the development of the Master Chemical Mechanism, MCM v3 (Part B): tropospheric degradation of aromatic volatile organic compounds, Atmos. Chem. Phys., 3, 181-193, doi:10.5194/acp-3-181-2003, 2003.

Jenkin, M. E., Wyche, K. P., Evans, C. J., Carr, T., Monks, P. S., Alfarra, M. R., Barley, M. H., McFiggans, G. B., Young, J. C., and Rickard, A. R.: Development and chamber evaluation of the MCM v3.2 degradation scheme for $\beta$-caryophyllene, Atmos. Chem. Phys., 12, 5275-5308, doi:10.5194/acp-12-5275$2012,2012$.
Karl, T. G., Christian, T. J., Yokelson, R. J., Artaxo, P., Hao, W. M., and Guenther, A.: The Tropical Forest and Fire Emissions Experiment: method evaluation of volatile organic compound emissions measured by PTR-MS, FTIR, and GC from tropical biomass burning, Atmos. Chem. Phys., 7, 5883-5897, doi:10.5194/acp-7-5883-2007, 2007.

Kaser, L., Karl, T., Guenther, A., Graus, M., Schnitzhofer, R., Turnipseed, A., Fischer, L., Harley, P., Madronich, M., Gochis, D., Keutsch, F. N., and Hansel, A.: Undisturbed and disturbed above canopy ponderosa pine emissions: PTR-TOF-MS measurements and MEGAN 2.1 model results, Atmos. Chem. Phys., 13, 11935-11947, doi:10.5194/acp-13-11935-2013, 2013.

Kitanovski, Z., Grgić, I., Yasmeen, F., Claeys, M., and Čusak, A.: Development of a liquid chromatographic method based on ultraviolet-visible and electrospray ionization mass spectrometric detection for the identification of nitrocatechols and related tracers in biomass burning atmospheric organic aerosol, Rapid Commun. Mass Sp., 26, 793-804, doi:10.1002/rcm.6170, 2012.

Lauraguais, A., Coeur-Tourneur, C., Cassez, A., Deboudt, K., Fourmentin, M., and Choël, M.: Atmospheric reactivity of hydroxyl radicals with guaiacol (2-methoxyphenol), a biomass burning emitted compound: Secondary organic aerosol formation and gas-phase oxidation products, Atmos. Environ., 86, 155-163, doi:10.1016/j.atmosenv.2013.11.074, 2014.

Lee, B. H., Lopez-Hilfiker, F., Mohr, C., Kurtén, T. C., Worsnop, D., and Thornton, J. A.: An Iodide-Adduct High-Resolution Timeof-Flight Chemical-Ionization Mass Spectrometer: Application to Atmospheric Inorganic and Organic Compounds, Environ. Sci. Technol., 48, 6309-6317, doi:10.1021/es500362a, 2014.

Lin, P., Liu, J., Shilling, J. E., Kathmann, S., Laskin, J., and Laskin, A.: Molecular Characterization of Brown Carbon (BrC) Chromophores in Secondary Organic Aerosol Generated From PhotoOxidation of Toluene, Phys. Chem. Chem. Phys., 17, 23312 23325, doi:10.1039/C5CP02563J, 2015.

Mohr, C., Lopez-Hilfiker, F. D., Zotter, P., Prévôt, A. S. H., Xu, L., Ng, N. L., Herndon, S. C., Williams, L. R., Franklin, J. P., Zahniser, M. S., Worsnop, D. R., Knighton, W. B., Aiken, A. C., Gorkowski, K. J., Dubey, M. K., Allan, J. D., and Thornton, J. A.: Contribution of Nitrated Phenols to Wood Burning Brown Carbon Light Absorption in Detling, United Kingdom during Winter Time, Environ. Sci. Technol., 47, 6316-6324, doi:10.1021/es400683v, 2013.

Morville, S., Scheyer, A., Mirabel, P., and Millet, M.: Spatial and Geographical Variations of Urban, Suburban and Rural Atmospheric Concentrations of Phenols and Nitrophenols, Environ. Sci. Pollut. R, 13, 83-89, doi:10.1065/espr2005.06.264, 2006.

Müller, M., George, C., and D'Anna, B.: Enhanced spectral analysis of C-TOF Aerosol Mass Spectrometer data: Iterative residual analysis and cumulative peak fitting, Int. J. Mass Spectrom., 306, 1-8, doi:10.1016/j.ijms.2011.04.007, 2011.

Natangelo, M., Mangiapan, S., Bagnati, R., Benfenati, E., and Fanelli, R.: Increased concentrations of nitrophenols in leaves from a damaged forestal site, Chemosphere, 38, 1495-1503, doi:10.1016/S0045-6535(98)00370-1, 1999.

Olariu, R. I., Klotz, B., Barnes, I., Becker, K. H., and Mocanu, R.: FT-IR study of the ring-retaining products from the reaction of $\mathrm{OH}$ radicals with phenol, o-, m-, and p-cresol, Atmos. Environ., 36, 3685-3697, doi:10.1016/S1352-2310(02)00202-9, 2002. 
Pankow, J. F.: An absorption model of the gas/aerosol partitioning involved in the formation of secondary organic aerosol, Atmos. Environ., 28, 189-193, doi:10.1016/1352-2310(94)900949, 1994.

Platz, J., Nielsen, O. J., Wallington, T. J., Ball, J. C., Hurley, M. D., Straccia, A. M., Schneider, W. F., and Sehested, J.: Atmospheric Chemistry of the Phenoxy Radical, C6H5O():? UV Spectrum and Kinetics of Its Reaction with $\mathrm{NO}, \mathrm{NO}_{2}$, and $\mathrm{O}_{2}$, The $\mathrm{J}$. Phys. Chem. A, 102, 7964-7974, doi:10.1021/jp9822211, 1998.

Rippen, G., Zietz, E., Frank, R., Knacker, T., and Klöpffer, W.: Do airborne nitrophenols contribute to forest decline?, Environ. Technol. Lett., 8, 475-482, doi:10.1080/09593338709384508, 1987.

Rubio, M. A., Lissi, E., Herrera, N., Pérez, V., and Fuentes, N.: Phenol and nitrophenols in the air and dew waters of Santiago de Chile, Chemosphere, 86, 10351039,doi:10.1016/j.chemosphere.2011.11.046, 2012.

Sander, R.: Compilation of Henry's law constants (version 4.0) for water as solvent, Atmos. Chem. Phys., 15, 4399-4981, doi:10.5194/acp-15-4399-2015, 2015.

Schwarzenbach, R. P., Stierli, R., Folsom, B. R., and Zeyer, J.: Compound properties relevant for assessing the environmental partitioning of nitrophenols, Environ. Sci. Technol., 22, 83-92, doi:10.1021/es00166a009, 1988.

Sekimoto, K., Inomata, S., Tanimoto, H., Fushimi, A., Fujitani, Y., Sato, K., and Yamada, H.: Characterization of nitromethane emission from automotive exhaust, Atmos. Environ., 81, 523531, doi:10.1016/j.atmosenv.2013.09.031, 2013.

Stark, H., Yatavelli, R. L. N., Kimmel, J. R., Bertram, T. H., Thornton, J. A., Jimenez, J. L., and Worsnop, D. R.: Cluster Formation and Ion Chemistry in the High Pressure Inlet of a Chemical Ionization Mass Spectrometer: Lessons learned from Field and Laboratory Studies, 22nd International Symposium on Gas Kinetics, 18-22 June 2012, Boulder, CO, 2012.

Stark, H., Yatavelli, R. L. N., Thompson, S. L., Kimmel, J. R., Cubison, M. J., Chhabra, P. S., Canagaratna, M. R., Jayne, J. T., Worsnop, D. R., and Jimenez, J. L.: Methods to extract molecular and bulk chemical information from series of complex mass spectra with limited mass resolution, Int. J. Mass Spectrom., 389, 26-38, doi:10.1016/j.ijms.2015.08.011, 2015.

Stockwell, C. E., Veres, P. R., Williams, J., and Yokelson, R. J.: Characterization of biomass burning emissions from cooking fires, peat, crop residue, and other fuels with high-resolution proton-transfer-reaction time-of-flight mass spectrometry, Atmos. Chem. Phys., 15, 845-865, doi:10.5194/acp-15-845-2015, 2015.

Tremp, J., Mattrel, P., Fingler, S., and Giger, W.: Phenols and nitrophenols as tropospheric pollutants: Emissions from automobile exhausts and phase transfer in the atmosphere, Water Air Soil Pollut, 68, 113-123, doi:10.1007/BF00479396, 1993.

Veres, P., Roberts, J. M., Warneke, C., Welsh-Bon, D., Zahniser, M., Herndon, S., Fall, R., and de Gouw, J.: Development of negative-ion proton-transfer chemical-ionization mass spectrometry (NI-PT-CIMS) for the measurement of gas-phase organic acids in the atmosphere, Int. J. Mass Spectrom., 274, 48-55, doi:10.1016/j.ijms.2008.04.032, 2008.
Vione, D., Maurino, V., Minero, C., and Pelizzetti, E.: Phenol photonitration upon UV irradiation of nitrite in aqueous solution I: Effects of oxygen and 2-propanol, Chemosphere, 45, 893-902, doi:10.1016/S0045-6535(01)00035-2, 2001.

Vione, D., Maurino, V., Minero, C., and Pelizzetti, E.: Aqueous Atmospheric Chemistry:? Formation of 2,4-Dinitrophenol upon Nitration of 2-Nitrophenol and 4-Nitrophenol in Solution, Environ Sci. Technol., 39, 7921-7931, doi:10.1021/es050824m, 2005.

Vione, D., Maurino, V., Minero, C., Duncianu, M., Olariu, R.-I., Arsene, C., Sarakha, M., and Mailhot, G.: Assessing the transformation kinetics of 2- and 4-nitrophenol in the atmospheric aqueous phase. Implications for the distribution of both nitroisomers in the atmosphere, Atmos. Environ., 43, 2321-2327, doi:10.1016/j.atmosenv.2009.01.025, 2009.

Warneke, C., Geiger, F., Edwards, P. M., Dube, W., Pétron, G., Kofler, J., Zahn, A., Brown, S. S., Graus, M., Gilman, J. B., Lerner, B. M., Peischl, J., Ryerson, T. B., de Gouw, J. A., and Roberts, J. M.: Volatile organic compound emissions from the oil and natural gas industry in the Uintah Basin, Utah: oil and gas well pad emissions compared to ambient air composition, Atmos. Chem. Phys., 14, 10977-10988, doi:10.5194/acp14-10977-2014, 2014.

Warneke, C., Veres, P., Murphy, S. M., Soltis, J., Field, R. A., Graus, M. G., Koss, A., Li, S.-M., Li, R., Yuan, B., Roberts, J. M., and de Gouw, J. A.: PTR-QMS versus PTR-TOF comparison in a region with oil and natural gas extraction industry in the Uintah Basin in 2013, Atmos. Meas. Tech., 8, 411-420, doi:10.5194/amt-8-4112015, 2015.

Wild, R. J., Edwards, P. M., Dube, W. P., Baumann, K., Edgerton, E. S., Quinn, P. K., Roberts, J. M., Rollins, A. W., Veres, P. R., Warneke, C., Williams, E. J., Yuan, B., and Brown, S. S.: A Measurement of Total Reactive Nitrogen, NOy, together with $\mathrm{NO}_{2}$, $\mathrm{NO}$, and $\mathrm{O}_{3}$ via Cavity Ring-down Spectroscopy, Environ. Sci. Technol., 48, 9609-9615, doi:10.1021/es501896w, 2014.

Yatavelli, R. L. N., Stark, H., Thompson, S. L., Kimmel, J. R., Cubison, M. J., Day, D. A., Campuzano-Jost, P., Palm, B. B., Hodzic, A., Thornton, J. A., Jayne, J. T., Worsnop, D. R., and Jimenez, J. L.: Semicontinuous measurements of gas-particle partitioning of organic acids in a ponderosa pine forest using a MOVI-HRToFCIMS, Atmos. Chem. Phys., 14, 1527-1546, doi:10.5194/acp14-1527-2014, 2014.

Yuan, B., Veres, P. R., Warneke, C., Roberts, J. M., Gilman, J. B., Koss, A., Edwards, P. M., Graus, M., Kuster, W. C., Li, S.-M., Wild, R. J., Brown, S. S., Dubé, W. P., Lerner, B. M., Williams, E. J., Johnson, J. E., Quinn, P. K., Bates, T. S., Lefer, B., Hayes, P. L., Jimenez, J. L., Weber, R. J., Zamora, R., Ervens, B., Millet, D. B., Rappenglück, B., and de Gouw, J. A.: Investigation of secondary formation of formic acid: urban environment vs. oil and gas producing region, Atmos. Chem. Phys., 15, 1975-1993, doi:10.5194/acp-15-1975-2015, 2015.

Zhang, X., Lin, Y.-H., Surratt, J. D., and Weber, R. J.: Sources, Composition and Absorption Ångström Exponent of Lightabsorbing Organic Components in Aerosol Extracts from the Los Angeles Basin, Environ. Sci. Technol., 47, 3685-3693, doi:10.1021/es305047b, 2013. 